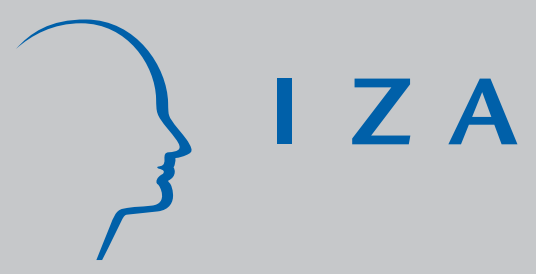

IZA DP No. 3911

Does the Minimum Wage Have a Higher Impact on the Informal than on the Formal Labor Market?

Evidence from Quasi-Experiments

Melanie Khamis

December 2008 


\title{
Does the Minimum Wage Have a Higher Impact on the Informal than on the Formal Labor Market? Evidence from Quasi-Experiments
}

\author{
Melanie Khamis \\ IZA and London School of Economics
}

Discussion Paper No. 3911

December 2008

\author{
IZA \\ P.O. Box 7240 \\ 53072 Bonn \\ Germany \\ Phone: +49-228-3894-0 \\ Fax: +49-228-3894-180 \\ E-mail: iza@iza.org
}

Any opinions expressed here are those of the author(s) and not those of IZA. Research published in this series may include views on policy, but the institute itself takes no institutional policy positions.

The Institute for the Study of Labor (IZA) in Bonn is a local and virtual international research center and a place of communication between science, politics and business. IZA is an independent nonprofit organization supported by Deutsche Post World Net. The center is associated with the University of Bonn and offers a stimulating research environment through its international network, workshops and conferences, data service, project support, research visits and doctoral program. IZA engages in (i) original and internationally competitive research in all fields of labor economics, (ii) development of policy concepts, and (iii) dissemination of research results and concepts to the interested public.

IZA Discussion Papers often represent preliminary work and are circulated to encourage discussion. Citation of such a paper should account for its provisional character. A revised version may be available directly from the author. 


\section{ABSTRACT \\ Does the Minimum Wage Have a Higher Impact on the Informal than on the Formal Labor Market? Evidence from Quasi-Experiments*}

This paper investigates a puzzle in the literature on labor markets in developing countries: labor legislations not only have an impact on the formal labor market but also an impact on the informal sector. It has even been argued that the impact on the informal sector in the case of the minimum wage is stronger than on the formal sector. Using quasi-experiments of minimum wage changes and thereby exploiting geographical variation of the minimum wage bite, I find evidence for this hypothesis. Informal workers, workers without social security contribution, experienced significant wage increases when the minimum wage was raised while formal workers did not. This result highlights that non-compliance with one labor legislation, the social security contribution, does not necessarily imply non-compliance to other labor laws such as the minimum wage.

JEL Classification: $\quad \mathrm{J} 31, \mathrm{~J} 42$

Keywords: minimum wages, informal economy, quasi-experiments

Corresponding author:

Melanie Khamis

IZA

Schaumburg-Lippe-Str. 5-9

53113 Bonn

Germany

E-mail: khamis@iza.org

\footnotetext{
* I would like to thank Omar Arias, Erlend Berg, Gabriel Demombynes, Emanuela Galasso, Paula Giovagnoli, Markus Goldstein, Jesko Hentschel, Steve Pischke and Diana Weinhold for their helpful discussions, advice and comments on various stages of this paper. I also would like to thank the participants of the 3rd IZA/World Bank Conference 2008 and LACEA 2008 for their comments. All errors are my own.
} 


\section{Introduction}

In some countries, the minimum wage is more effective among those who are regarded as informal workers than in other segments of the labor markets. ${ }^{1}$

Minimum wages and the evaluation of their impact on the labor market have been central in the empirical literature for many years (Card and Krueger 1995). Recently, the focus has shifted towards the minimum wage in developing countries and their heterogeneous labor markets. Here, the hypothesis has been put forward that labor market regulations, the minimum wage being one of them, directed at the formal labor market affect the informal labor market (Harrison and Leamer 1997). This was also highlighted by the above quote, which proposes an even stronger hypothesis: labor market regulations directed at the formal labor market affect the informal labor market more than the formal labor market. Empirical evidence on this is very sparse in the literature and a need for further research in the area of labor market policies and regulations for several Latin American countries, including Argentina, was emphasized in the literature (IADB 2004; Heckman and Pages 2003).

Using two quasi-experiments in the application of econometric techniques from the developed country minimum wages literature, this paper investigates the impact of minimum wage increases on the formal and informal labor market of a developing country. Moreover, it is of interest to see whether the impact provides evidence for the hypothesis that the minimum wage is more applicable in the informal segment of the labor market than the formal segment. This paper finds support for this hypothesis when looking at two minimum wage changes, 1993 and 2004, in Argentina, a country with a large degree of labor informality. A significant wage increase was found for the overall and the informal wage distribution after minimum wage changes while this was not the case for the formal wage distribution.

In the next section some of the most related literature and previous findings are presented. Thereafter background on minimum wages and informality in Argentina and available data are discussed. In the fourth section I describe my empirical strategy and obtained results, with tests for the applicability of the empirical strategy and a

\footnotetext{
${ }^{1}$ Quote from Enrique V. Iglesias, Former President of Inter-American Development Bank, IADB (2004)
} 
robustness check. In the conclusion the contribution and implications of these results for policy are considered.

\section{Minimum wages and the informal sector}

Minimum wage policies are not only a common labor market feature in developed countries, but also in many developing countries in Latin America, Africa, the Middle East and Asia (Mazumdar, 1989). This section briefly reviews some theoretical considerations of the impact of minimum wage policies on the formal and informal labor market in developing countries. In addition to that the most relevant existing empirical evidence for developing countries is presented.

\subsection{Theory}

Theoretical considerations on the impact of the minimum wage depends on the view of the labor market and its dynamics in developing countries, where the informal labor market coexist alongside the formal segment of the labor market. Government interventions potentially have differential impacts on the formal and informal labor market.

In the traditional dualistic labor markets the view prevails that these two labor markets, formal and informal, are segmented by nominal wage rigidities such as the minimum wage (Harris and Todaro 1970; Mazumdar 1989). Following the two-sector model of the labor market of Mazumdar (1989), one can observe competitive market wages and full employment before the introduction of the minimum wage in covered (formal) and uncovered (informal) sector. After the introduction of the minimum wage, which increases the formal sector wage, some workers become unemployed in the formal labor market. Some of these workers might decide to remain unemployed and wait for a job in the formal sector. Other displaced workers might seek employment in the informal sector. This would increase the labor supply in the informal labor market and thereby driving down the informal sector wage. The informal labor market would clear at a wage level below the competitive wage.

The minimum wage impact here would result in an increase in formal wages and a decrease in informal wages. In terms of employment the effects are the opposite: a decrease in employment in the formal sector and an increase in employment in the 
informal sector (Harrison and Leamer 1997). The magnitudes of these effect crucially depend on minimum wage effectiveness on wages and on the labor demand elasticity (Mazumdar 1989).

This, tough, are not the only potential impacts of the minimum wage on wages and employment in the formal and informal sector. Three possible channels how the minimum wage might potentially increase informal wages are identified in the literature (Bird and Manning 2002):

(1) Minimum wages due their redistributive nature can increase income not only in the formal sector but also in the informal sector (Saget 2001; Lustig and Mcleod 1996; Carruth and Oswald 1981). For instance, in this framework the formal sector wage increase due to the minimum wage could lead to capital reallocation into the laborintensive informal sector, which in turn would raise informal sector wages (Harrison and Leamer 1997).

(2) The minimum wage has a positive impact on informal wages through linkages of the labor and goods market (Fizsbein 1992). The assumption of a high employment share of the informal sector and formal sector workers as main buyers of the informal sector products is crucial for this result and highly dependent on the particular elasticities of the demand and supply effect of the minimum wage (Bird and Manning 2002). An increase in formal sector wages would increase the demand for goods and services produced in the informal sector, which leads to an increase in informal sector wages. Also this model assumes a relatively homogeneous informal labor market, which has been contested in the literature (Fields 1990).

(3) The minimum wage is used as a 'benchmark' for what is considered fair remuneration in the labor market. The minimum wage is employed as numeraire and thereby wages and benefits are quoted in multiples of the minimum wage (Maloney and Nunez 2003).

These three channels are put forward by the literature as potential explanations for the so-called lighthouse effect of the minimum wage on the informal wage distribution, which is tested in recent empirical literature for developing countries. 


\subsection{Empirical evidence in developing countries}

The empirical literature on the minimum wage impact for developing countries is still relatively small, but growing, and lacks empirical evidence for many developing countries (Lemos 2004). For Brazil and Indonesia the empirical literature on the minimum wage impacts is more exhaustive than for other developing countries, which is shortly reviewed here. Thereafter a summary of the previous sparse empirical research on Argentina is also described.

In the Brazilian studies of the minimum wage authors generally find that the minimum wage compressed the wage distribution for formal and informal labor market (Carneiro 2000; Corseuil and Carneiro 2000; Corseuil and Morgado 2000; Fainzylber 2001; Lemos 2004ab; Neri, Gonzaga and Camargo 2001; Maloney and Nunez 2003; Amado, Gill and Neri 2002). ${ }^{2}$ On the employment effects some mixed results are obtained tough. On one hand studies suggested a small negative employment effect in both sectors (Fajnzylber 2001; Lemos 2004b); on the other hand other studies suggest a negative employment effect in the formal labor market and a positive effect on the informal labor market (Carneiro 2000).

For Indonesia the minimum wage impact on the formal and informal labor market indicates that the average wage for different subgroups of the labor market increases after minimum wage changes (SMERU 2001; Rama 2001). However, at the same time for a segment of the informal sector a negative wage impact is found (Bird and Manning 2002). In terms of employment impact a negative employment effect is found among small, domestic firms or young and female workers (SMERU 2001; Alatas and Cameron 2003; Rama 2001). This is contradicted by findings of informal employment increases (Bird and Manning 2002).

Empirical evidence of the impact of the minimum wage on the informal sector has been found in several Latin American countries (Grindling and Terrell 2004; Montenegro and Pages 2003; Castillo-Freeman and Freeman 1991; Bell 1997; Maloney and Nunez 2003). Several previous studies on the Argentine minimum wage have found evidence of the impact of the minimum wage on wages and employment in the informal sector (Fizsbein 1992; FIEL 2000; Szretter 2004; Kostzer 2006; SEL Consultores 2006; Kristensen

\footnotetext{
${ }^{2} \mathrm{~A}$ comprehensive overview of the literature on the effects of the minimum wage in Brazil can be found in Carneiro (2001) and Lemos (2004b).
} 
and Cunningham 2006).

In his study Beccaria (2004), who uses probit analysis to estimate the probability of an individual remaining in the same labor market status after the minimum wage change as before the minimum wage change, investigates the minimum wage impact on salaried and non-registered workers. Following a panel for Greater Buenos Aires for the period May to October 1993, he finds that the minimum wage has no significant impact on employment. In his analysis he leaves out potential wage impacts and does not take advantage of the federal minimum wage as a feature to be exploited in the estimation strategy for the 1993 minimum wage change.

For the recent minimum wage hikes after the Argentine crisis in 2001/02 Kostzer (2006) analyses the changes of the minimum wage with descriptive analysis of household survey data and finds that the minimum wage seems to have a higher impact on informal sector workers. He argues that further empirical analysis of the minimum wage impact on the informal sector is needed. SEL Consultores (2006) also conduct a descriptive analysis and come to the same conclusion.

None of these studies on the Argentine minimum wage though have employed the tools, kernel density distributions and difference-in-difference estimates, advocated in the minimum wage literature for developed and developing countries to study minimum wage changes and their impact on the formal and informal labor market. The only studies by Maloney and Nunez (2003) and Kristensen and Cunningham (2006) that examine the minimum wage in Argentina, among other countries in Latin America, employed Kernel density wage distribution and found evidence in this analysis of the minimum wage impact on the informal segment of the labor market. The focus of these studies tough was not on minimum wage changes, and the kernel density wage distributions were only studied for one time point, 1998 or 2000 respectively.

Contrary to the previous literature my paper exploits the institutional features of the federal minimum wage changes using empirical tools, kernel density distribution and difference-in-difference estimation, from the U.S. and U.K. minimum wage literature to substantiate the claim of an impact and even a higher impact of the minimum wage on the informal sector's wage distribution. 


\section{Background and data ${ }^{3}$}

In this section I discuss the background, history and developments over the period 19922005 of minimum wages in Argentina, where the two quasi-experiments of minimum wage changes occurred. In addition to that informality in the labor market, the definition and development over this period, are also highlighted. Thereafter the household survey data analyzed in this paper are described.

\subsection{Background on minimum wages and informality}

\subsubsection{Minimum wage history and developments in Argentina}

In 1950 Argentina ratified the ILO convention on the minimum wage, which was rather unspecific in terms of the minimum wage level, frequency and regulation of minimum wage changes (Bienen, 2002). In 1964 the minimum wage was introduced officially in the Argentine labor law. By definition, the Argentine minimum wage intended to enable every employee, that works 200 hours per month, to be able to afford sufficient food, accommodation, education, clothing, health care and transport. According to this law, no worker should be paid less than the minimum wage. A national tripartite body of representatives of the state, employers and employees, a national council, was established to determine the minimum wage level and adjustments. However, some changes in the law took place in 1978 and 1991, which granted more authority to the government, the Ministry of Labor, in the minimum wage setting of this national council. The minimum wage is set at federal level and no province-level minimum wages exist.

Developments of the minimum wage changes and increases are displayed in Table 1. The two minimum wage changes of interest in this paper were the minimum wage change in July 1993 and September 2004.

In July 1993, after the hyperinflation period in Argentina with several minimum wage changes to adjust for the erosion due to persistent inflation, the first official real minimum wage change of the 1990s increased the minimum wage from 97 pesos to 200 pesos in nominal terms per month in July 1993. For the period 1992 to 2005 these real and nominal minimum wage developments in Figure 1 show that after the July 1993 increases in both real and nominal terms, a period of stable real and nominal wages

\footnotetext{
${ }^{3}$ Figures and Tables in Appendix 1.
} 
followed, with hardly any divergence between these two measures. The nominal level of 200 pesos was maintained until after the crisis in 2001. In 2001 during the onset of the Argentine economic crisis a huge deterioration in the minimum wage in real terms occurred, bringing the real minimum wage to a level before the 1993 change.

Only in July 2003, about 10 years after the last minimum wage increase, the labor minister authorized an increase in the minimum wage for the first time in a decade. The minimum wage was augmented from 200 pesos to 250 pesos per month and thereby started a minimum wage hike in the following months, where the July level of 250 pesos was increased by gradual 10 pesos until 300 pesos in December 2003. In January 2004 the minimum wage was fixed at 350 pesos (MTSS 2004). These minimum wage changes after the economic crisis of 2001/02 were implemented by the Argentine government without the national council. The government argued that the minimum wage increases were necessary to counter the price increases after the economic crisis and for this reason were only re-instating the minimum wages effectiveness to pre-crisis level (ME 2005). As Figure 1 shows the minimum wage increases beginning in 2003 brought the minimum wage back to higher levels in real terms.

In August 2004 the national council met and decided a further now official minimum wage increase to 450 pesos for September 2004. Figure 2 examines the recent minimum wage changes through an analysis of the actual purchasing power of a basic basket of goods for Buenos Aires during the period 2000 to 2005, assuming the minimum wage is paid for 200 hours worked in a month (ME 2005). ${ }^{4}$ After the large deterioration of the minimum wage from the crisis and its subsequent recovery due the minimum wage increases after July 2003, the increase to 450 pesos was the first minimum wage increase to raise the minimum wage further than the actual pre-crisis levels. The hours worked to obtain a basket of basic good decreased for the first time since October 2000.

Both Figure 1 and Figure 2 showed that the two minimum wage changes, which I analyze, in July 1993 and September 2004 were in fact real minimum wage changes and therefore one would expect these changes to have an impact on the labor market.

\footnotetext{
${ }^{4}$ This basic basket differs from the official basket as it includes even fewer goods (ME 2005). It includes the basic goods and prices for the following items per month for which I collected the price data and estimated the hours of work needed to obtain this basket: Beef $6 \mathrm{~kg}$, Milk 7.5l, dry noodles 4.5 $\mathrm{kg}$, rice $3 \mathrm{~kg}$, flour $1.5 \mathrm{~kg}$, potato $6 \mathrm{~kg}$, tomoatoes $9 \mathrm{~kg}$, bread $6 \mathrm{~kg}$, coffee $600 \mathrm{~g}$, banana $9 \mathrm{~kg}$, sugar $3 \mathrm{~kg}$, oil $900 \mathrm{ml}$ and butter $750 \mathrm{~kg}$.
} 


\subsubsection{Informality in the labor market}

To estimate the impact of minimum wage changes on the formal and informal labor market, the definition of informality in the labor market and the development of informality over the time period of the two minimum wage changes are important.

In this paper the definition of informality is as follows: A worker is an informal worker if he/she does not have access or rights to a pension. This is coded from the Argentine individual household survey questionnaire. Other definitions of labor informality, such as the ILO classification of low-productivity, unskilled, marginal jobs as informal work, exist for Argentina (Gasparini 2003: World Bank 2006). Here, the legalistic definition, which is more closely linked to the ideas of De Soto (1989) about the nature of the informal sector, was employed to analyze the coverage of two labor laws and regulations, the minimum wage and social security contributions, and the impact of changes in the minimum wage. Workers without social security coverage might still earn the minimum wage and changes in the minimum wage might increase the wages in the informal sector.

This is also pointed out by Marshall (2004, p.10):

Non-compliance needs not be uniform, for instance, evasion of social security contributions can go hand in hand with compliance with the minimum wage [...], and in depth studies, are needed to establish which legal constraints tend to be applied, and which tend to be evaded.

In Figure 3 the development of the share of informal workers over the period 1990 to 2005 increased. A rapid increase in informality occurred after the 2001/02 crisis. For the period around the two minimum wage changes, 1993 and 2004, the informality share in the labor market remained relatively stable.

\subsection{Data}

For the estimations in this paper I mainly worked with the Argentine national household surveys, the Permanent Household Survey (EPH) for the year 1993 and the Continuous Permanent Household survey (EPH-C) for the year 2004. For 1993 the May and October waves around the July minimum wage change and for the 2004 the second trimester and fourth trimester waves around the September minimum wage change were worked with in 
the estimations. In terms of data and the possible estimations this gives rather a shortterm effect. However, longer-term effects through the use of 1994 or 1992 data would be very hard to account for in an economy like Argentina. In addition to that, the data available for those years differed slightly from the May and October 1993 waves. For this reason taking the immediate household survey proceeding and following the minimum wage policy change seemed most appropriate. Seasonal variation between the May and October rounds of the survey does not dramatically affect most statistics as the surveys cover only urban areas (CEDLAS, 2004, citing INDEC (2001)). ${ }^{5}$

These household surveys cover about 31 urban areas in the country and thereby cover about 60 percent of the Argentine population. The urban coverage was extended over the years. The surveys in the early 1990s, also the one in 1993, do not cover all the areas consistently. Still, this includes the major urban areas of Argentina. In the estimation only urban areas, which are in the May and October wave for 1993 are included. So, in fact the repeated cross-section of urban areas was employed in the estimations. In the trimester data for 2004 the codes for a restricted set of urban areas were provided by the National Statistical Office (INDEC).

The individual and household questionnaires covered questions relating to demographics, education, income, social security contribution and the labor market. The household survey is a rotating panel of urban households. The panel structure identification, although the individuals are repeated in the survey, is difficult in the early 1990s due to the lack of codes provided by INDEC. In the new EPH-C also some of the explicit codes for the identification of the panel were not provided as well.

The minimum wage data were collected from the Argentine Ministry of Labor and the Ministry of Economy (MTSS 2004; ME 2005). GDP per province was obtained from Province of Buenos Aires Ministry of Economy and CPI and price data were collected from INDEC.

\footnotetext{
${ }^{5}$ Adjustment for seasonality does not seem to be necessary in this case. Moreover, the data limitations, in terms of comparability of regions between 1992 and 1993, would make this difficult.
} 


\section{Empirical tests of the impact of minimum wage changes on the informal sector}

This section describes the empirical tests and results for the impact of the Argentine minimum wage changes on the formal and informal labor market. In the first subsection I discuss the empirical strategy for the 1993 minimum wage change and in the second subsection the results are presented. In the third subsection a simple robustness check, using the 2004 minimum wage change, is described.

\subsection{Empirical strategy for the 1993 minimum wage change}

In the U.S. and U.K. empirical literature on the minimum wage it has now become quite standard to exploit the occurrence of a minimum wage change, a quasi-experiment, as a source of exogenous variation (Card and Krueger 1995; Card 1992ab). To estimate the causal effect of minimum wages a difference-in-difference estimator before and after the minimum wage change is usually estimated for outcome variables for two groups, the treatment and control group. The main issue is the definition of treatment and control group as the control group provides valuable information in the absence of treatment, the counterfactual. For instance, comparable individuals at higher levels of the wage distribution can constitute the control group for the minimum wage earners (Currie and Fallick 1996; Pischke and Acemoglu 2003). However, for this to be a valid control group it would require that we assume that there is no effect of minimum wage changes on multiples of the minimum wage. Another commonly used control and treatment group follows the well-known fast-food restaurant experiments in an affected state and not affected state by a minimum wage change (Card and Krueger 1995). Given that the Argentine minimum wage might have a potential ripple effect at higher levels of the wage distribution and is also a national minimum wage, these two methods are not applicable to form control and treatment group.

Still, it is possible to design a control and treatment group for a national minimum wage change while exploiting regional variation. As Card (1992a) pointed out that 'the national minimum wage is an under-appreciated asset from the evaluation point of view'. The federal minimum wage in combination with a high regional wage variation could be used in the assessment of the impact of a minimum wage change (Card 1992a; Card and 
Krueger 1995 chapter 4; Stewart 2002).

The regional wage variation implies that the minimum wage change would affect an initial proportion of 'low-paid' workers below the new minimum wage in each state, varying across the different states. The minimum wage bites to differing degrees in an area's wage distribution. The treatment and control group are defined according to the potential differential impact or bite of the new minimum wage in the urban areas. The assignment of area $a$ into control group, the low impact group, and into treatment group, the high impact group, is determined by this initial proportion of below the new minimum wage earners in the area. The differential impact of the minimum wage is the source of exogenous variation in this estimation strategy.

The mean treatment on the treated effect, which is the impact on the high impact group, is estimated as the following difference-in-difference estimator

$$
\hat{\theta}_{D I D}=\left(\bar{Y}_{a t}-\bar{Y}_{a t-1}\right)_{H I}-\left(\bar{Y}_{a t}-\bar{Y}_{a t-1}\right)_{L I}
$$

where the first bracket represent the two-period difference of the mean outcome variable $\bar{Y}$ for the high impact group $H I$ at time $t$, after the minimum wage change, and at time $t-1$, before the minimum wage change. Analogously, the second bracket is the two-period difference of the mean outcome variable $\bar{Y}$ for the low impact group $L I$. Here, the outcome variable $\bar{Y}$ is wages, total, formal or informal sector. This estimator is obtained from the following regression

$$
Y_{a t}=\gamma_{0}+\gamma_{1} M_{t}+\gamma_{2} D_{a}+\theta M_{t} D_{a}+\varepsilon_{a t}
$$

where $M_{t}$ is a time dummy that takes the value 1 for October 1993 and 0 for May 1993. The treatment dummy $D_{a}$ takes the value 1 if area $a$ is in the high impact group and 0 if area $a$ is in the low impact group. The interaction term $M_{t} D_{a}$ is a dummy variable for the observation being in the high impact group after the minimum wage increase. Hence, $\theta$ is the true causal effect of the treatment on the outcome for this group, which in turn is the estimator of interest $\hat{\theta}_{D I D}$ here.

The key identifying assumption for the difference-in-difference estimator here is that $\theta$ would be 0 in the absence of 'treatment'. Basically, the underlying trend in outcome variable, wages, across the urban areas, control and treatment group, is assumed to be 
the same in the absence of the minimum wage. Clearly, this can be a potential problem to this type of estimation, a treat to validity (Meyer 1995).

Other factors could influence the results and this in turn would make the identification of an effect of a minimum wage change on $\bar{Y}$ doubtful. Here, the error term $\varepsilon_{a t}$ can be decomposed into several effects, individual specific and common macroeconomic effects, which cancel out through differencing. ${ }^{6}$ For instance, if macroeconomic effects were to systematically differ between high and low impact groups then the differencein-difference estimator here would be biased. The inclusion of a vector of characteristics $X_{a t}^{\prime}$ as controls in the estimation of (2) can adjust for observable difference between the observations of the two groups.

Thus the regression equation would be

$$
Y_{a t}=\gamma_{0}+\gamma_{1} M_{t}+\gamma_{2} D_{a}+\theta M_{t} D_{a}+X_{a t}^{\prime} \delta+\varepsilon_{a t}
$$

In my estimations I adjusted for potential group level differences, which might lead the minimum wage policy to systematically differ among the groups. In particular the concern was that the minimum wage policy might interact differently with the local labor market or economy across the high impact and low impact groups over time.

The main identifying assumption of equal trends in the outcomes for the high impact and low impact groups is crucial. For example, during this time period a shift in a sectoral industry to an industry, which employs more formal workers, in one area might change the impact of the minimum wage policy. Another possibility could be also a local area recovery, which is unrelated to the minimum wage increase, but might have an impact on wages (Meyer 1995; Angrist and Krueger 1999). To account for these potential problems controls for the industry sector, the regional gross domestic product and individual level controls, like age, gender and education were introduced during the estimations.

\footnotetext{
${ }^{6}$ Individual-level standard errors need to allow for possible correlation between the error terms within a local urban area and need to be adjusted for by clustering. The coefficient and sign remain the same but the standard error would be different when clustered by urban area.
} 


\subsection{Results $^{7}$}

This section presents the results for the Argentine minimum wage change in 1993. First, two tests for the applicability of the proposed estimation strategy are offered. The first test examines whether the minimum wage does have an effect on the wage distribution of the formal and informal labor market or not. The second test inspects whether there is a degree of geographical variation in the area wage distributions or not. After these two tests, I discuss the difference-in-difference estimation results.

\subsubsection{Test for minimum wage effect on wage distribution}

Before estimating the impact of the minimum wage on the formal and informal sector with the proposed empirical strategy, a test of whether the minimum wage has an impact on the wage distribution, is in fact binding, was performed. Kernel wage densities for the formal and informal wage distribution show that the informal wage distribution lies to the left of the formal wage distribution (Figure 4). This result is consistent with the findings by Maloney and Nunez (2003) for a different time period. The lower tails of the Kernel wage densities show that the informal wage distribution has spikes around the old and new minimum wage levels, 97 and 200 pesos respectively, while the formal wage distribution does not (Figure 5). From the cumulative wage distribution one can observe that the lower end of the informal cumulative distribution lies above the formal distribution (Figure 6). A higher percent of informal workers is allocated at the lower end of the wage distribution than formal workers at those wage levels. Cliffs or steps in the distribution indicate whether the minimum wage is binding at these wage level. A clustering of workers at these wage levels point to the minimum wage being binding at those levels (Kristensen and Cunningham 2006). In the informal cumulative distribution the steps are slightly more pronounced than for the formal distribution.

\subsubsection{Test for geographical variation}

For the specific estimator $\hat{\theta}_{D I D}$ based on comparing high impact and low impact groups of urban areas in Argentina to give believable results, certain conditions need to be satisfied first:

\footnotetext{
${ }^{7}$ Figures and Tables in Appendix 1. Descriptive Statistics and Variable Description in Appendix 2.
} 
(1)Wage distributions of the two groups, high impact and low impact, need to be significantly different from each other (Stewart 2002).

(2) A significant relationship with the fraction of workers in an area initially below the new minimum wage and the wage movements is necessary (Stewart 2002).

The main interest here it to test the variation of the minimum wage's bite in the different urban areas wage distributions as this determines the distinction between treatment and control group, high impact and low impact. ${ }^{8}$

An initial look at the Kernel density wage distributions by urban areas for total labor income provides an insight into the different area wage distributions (Figure 7). The variation of the bite, the proportion of workers below the new minimum wage of 200 pesos (depicted by the second vertical line) varies, although at the lower end of the wage distribution in each urban area, greatly between urban areas. In Figure 8 the percentage below the new incoming minimum wage is plotted by area. Clearly, there are several urban areas, which exhibit a higher share of people below the new minimum wage. ${ }^{9}$ These form the high impact group while the remaining are classified as the low impact group. The Kernel wage densities for the high impact and low impact groups have very different wage distributions as the distribution of the high impact group is located to the left of the distribution for the low impact group (Figure 9). This result is very similar to Stewart (2002) who uses this econometric methodology for the U.K. minimum wage introduction. Also following Stewart (2002), the two-period change for different aspects of an area's wage distribution is illustrated in Figure 10. Moving from areas with a low proportion of employees paid below the new minimum wage to areas with high percentage of below the minimum wage, the first percentile of the wage distribution increases rapidly. Contrary to this the median and mean of the distribution change relatively little and certainly do not increase (Stewart 2002). This yet again is further evidence for geographical variation of the different urban areas at the lower end of the wage distribution, where the minimum wage change bites.

\footnotetext{
${ }^{8}$ To include the entire variation in the bite instead of a dichotomous classification of high impact and low impact could be an alternative estimation strategy. In this paper I have followed the estimation strategy of Stewart (2002) of high impact and low impact groups.

${ }^{9}$ The local areas of Jujuy, Salta, Tucuman, Catamarca and Parana have the highest percentage. These areas form the high impact group and the remaining areas the low impact group.
} 


\subsubsection{Difference-in-difference estimation results}

The tests for binding of the minimum wage and geographical variation, validate the use of the empirical strategy outlined earlier and the estimations performed follow the template of Stewart (2002) and Card (1992a). For the estimations of the wage outcomes, area-level (unweighted) and individual-level (weighted) estimates, where the standard error was adjusted for clustering were calculated without and with controls (Table 2 to Table 4). From the area-level estimations, small positive, not significant coefficients for the informal wage are obtained. The wage impacts for former workers had large positive coefficients, but they were not significant either. The overall wage had a coefficient that was negative and not significant. As none of the coefficients were significant tough, the conclusion from this mean area-level estimations seems that there was no wage impact of the minimum wage change (Table 2). Contrary to this, the individual estimations without controls produced a positive significant impact for the informal wage and overall wage. For the formal sector wage it was also positive and not significant (Table 3). Here, the wage impact of the minimum wage change has an impact on the informal sector wage and wages in general. With the inclusion of a combination of different controls, local area and individual controls, the magnitude of the difference-in-difference estimates increased for all the wage segments and measures (Table 4$).{ }^{10}$

Overall, it is possible to say that there seems to be a significant positive impact on the informal sector wage and the overall wage distribution. The formal sector wage does not exhibit these properties and remains not significant.

Throughout the estimations data limitations in terms of urban coverage, as mentioned might still result in potentially biased results and a robustness check with another minimum wage change seems appropriate.

\subsection{A robustness check - the 2004 minimum wage change}

To check whether the results for the difference-in-difference estimator for 1993 are in fact robust, I perform a robustness check with another minimum wage change in 2004. Given data limitations due to changes in the household survey, it was not possible to apply the same difference-in-difference estimator. Bearing also in mind that the minimum

\footnotetext{
${ }^{10}$ Gender, age and education were the individual sector controls. GDP per province and and industry sectors were the local area controls.
} 
wage change in September 2004 occurred after a period of increases in informality in the labor market, related and unrelated to the Argentine economic crisis in 2001/02, Kernel density distribution for the informal wage before the minimum wage change showed a clear spike at the old minimum wage of 350 pesos, which was the current minimum wage in the second trimester 2004 (Figure 11). The formal sector wage distribution does not display any spike at all while the informal wage distribution does. The cumulative distribution also exhibits a concentration and small cliff in the informal sector wage and even small one for the formal wage (Figure 12). For the fourth trimester 2004, after the minimum wage increase to 450 pesos, the Kernel density for both, formal and informal sector exhibit a spike and even a plateau around the minimum wage while the cumulative distribution again shows a small jump at the minimum wage (Figure 13 and Figure 14). Hence, the minimum wage has a continued impact on the wage distribution of the informal sector and its change effects the informal wage.

\section{Conclusion}

The impact of labor laws and regulations on the informal labor market has been the focus of the literature on developing country labor markets. This paper tested empirically the hypothesis often mentioned that the minimum wage does have an impact on the informal labor market, possibly even a stronger impact on the informal than formal labor market. Exploiting quasi-experiments of minimum wage changes and applying econometric techniques, kernel density graphs and difference-in-difference estimation, employed by the minimum wage literature in the U.S. and the U.K. (Card 1992ab; Card and Krueger 1995; Stewart 2002), I found empirical support that the minimum wage and minimum wage changes have an impact on informal wages and even a higher impact on informal sector wages than formal sector wages. The difference-in-difference estimations for the 1993 minimum wage change showed a significant positive impact on informal sector wage distribution and on overall wages. These results were robust when looking at the kernel densities of a 2004 minimum wage change. Data limitations with respect to the geographical coverage did not allow an extension of the difference-in-difference estimator to the 2004 case, which only allows visual inspections of the kernel densities. This makes the findings for 2004 less convincing than the 1993 minimum wage analysis based on kernel densities and difference-in-difference estimates. 
Following up the quote in the introduction with empirical evidence, the Argentine minimum wage is more effective among those who are regarded informal sector workers than in other segments of the labor market. ${ }^{11}$ A lighthouse effect, a term employed if the minimum wage affects the wage determination in the informal sector, is found to be the case for Argentina.

These results are not only interesting for the Argentine case, but also contribute to the broader debate on the view of the labor market. In the traditional view of the dual labor market by Harris and Todaro (1970) the informal sector would have experienced a wage decrease due to minimum wage increases in the formal sector. After the minimum wage increase in the formal sector, some unemployed workers of the formal sector would seek employment in the informal sector, thereby driving informal sector wages down. Yet, the results in this paper do not support this view of the labor market as an increase of informal sector wages, even stronger than formal sector wages, was estimated. The overall effect of the minimum wage was dominated by the informal sector. The dualistic model of the segmented labor markets does not seem to apply universally to developing country labor markets. The idea put forward that the minimum wage might serve as a reference wage and non-compliance with labor legislation is not practised on all levels seems to apply (Marshall 2004). Employers might pay the minimum wage but not comply with the social security registration (Marshall 2004; Kostzer 2006; Kristensen and Cunningham 2006). The other theoretical explanations for the minimum wage impact on the informal sector wage, which might involve second round impacts of the minimum wage change, might play a role. However, due to the short-term effects of minimum wages changes on the informal sector, investigated in this paper, these explanations might be secondary.

These findings raise the question which sets of policies, not necessarily labor market policies, are appropriate to address compliance with minimum wages and social security contribution. To investigate this future research on what barriers and incentives exist on the employer level to comply with the minimum wage and not the social security system would provide further insight into the appropriate design of policies to address this dimension of formality-informality interaction in the labor market.

\footnotetext{
${ }^{11}$ It could even be argued from the visual inspection of the formal wage distribution that the minimum wage does not bite very much for formal sector workers. This could be a further explanation for the observed results.
} 


\section{References}

[1] Acemoglu, Daron and Joern-Steffen Pischke. 2003. "Minimum Wages and On-thejob Training," Research in Labor Economics 22: 159-202.

[2] Alatas, Vivi and Lisa Cameron. 2003. "The impact of minimum wages on employment in a low income country: an evaluation using the difference-in-differences approach." World Bank Policy Research Working Paper No. 2985.

[3] Amadeo, Edward, Indermit Gill and Marcelo Neri. 2000. "Brazil: The pressure points in labor legislation." Ensaios Economicos da EPGE 395 Rio de Janeiro.

[4] Angrist, Joshua D. and Alan B. Krueger. 1999. "Empirical Strategies in Labor Economics. " in Handbook of Labor Economics. Orley Ashenfelter and David Card ed.: Elsevier.

[5] Beccaria, Luis. 2004. "Efectos del salario minimo y de la asignacion no remunerativa." OIT Buenos Aires Serie documentos de trabajo 6.

[6] Bell, Linda. 1997. "The impact of minimum wages in Mexico and Colombia." Journal of Labor Economics 15(3): 120-134.

[7] Bienen, Derk. 2002. "Mindestlohnreformen in Suedamerika-oekonomische Rechtfertigung und praktische Umsetzung." Diskussionsbeitrag Nr.90, Georg-August Universitaet Goettingen.

[8] Bird, Kelly and Christ Manning. 2002. "The impact of the minimum wages on employment and earnings in the informal sector." Working Paper for 8th East Asian Economic Association Conference in Kuala Lumpur.

[9] Card, David. 1992a. "Using regional variation in wages to measure the effects of the federal minimum wage." Industrial and Labor Relations Review 46(1): 22-37.

[10] Card, David. 1992a. "Do minimum wages reduce employment? A case study of California 1978-89." Industrial and Labor Relations Review 46(1): 38-54.

[11] Card, David and Alan B. Krueger. 1995. Myth and Measurement-The new economics of the minimum wage. Princeton, New Jersey: Princeton University Press. 
[12] Carneiro, Francisco Galrao. 2000. "Time-series evidence on the employment effects of minimum wages in Brazil." Texto Para Discussao No 18, Catholic University Brasilia.

[13] Carneiro, Francisco Galrao. 2001. " An overview of the effects of the minimum wage on the Brazilian labor market." Working Paper, Catholic University of Brasilia.

[14] Carruth, Alan and Andrew J. Oswald. 1981. "The determination of union and nonunion wage rates." European Economic Review 16: 285-302.

[15] Castillo-Freeman, Alida and Richard B. Freeman. 1991. "Minimum wages in Puerto Rico: textbook case of a wage floor?" NBER Working Paper No.3759.

[16] CEDLAS. 2004. "Monitoring the Socio-Economic Conditions in Argentina, Chile, Paraguay and Uruguay - Argentina." Research report for the World Bank: Buenos Aires.

[17] Corseuil, Carlos Henrique and Francisco Galrao Carneiro. 2001. "Os Impactos Do Salario Minimo Sobre Emprego e Salarios No Brasil: Evidencias A Partir De Dados Longitudinais e Series Temporais." Texto Para Discussao No.849, Rio de Janeiro.

[18] Corseuil, Carlos Henrique and W. Morgado. 2001. "Salario minimo, distribuicao de salarios e emprego no Brasil." IPEA working paper.

[19] Currie, Janet and Bruce C. Fallick. 1996. "The minimum wage and the employment of youth evidence from the NLSY." The Journal of Human Resources 31(2): 404-28.

[20] De Soto, Hernando. 1989. The other Path. Harper and Row.

[21] Fajnzylber, Pablo. 2001. "Minimum wage effects throughout the wage distribution: evidence from Brazil's formal and informal sectors." Anais do XXIX Encontro Nacional de Economia.

[22] Fizsbein, Ariel. 1992. "Do workers in the informal sector benefit from cuts in the minimum wage?" World Bank Policy Research Working Paper No.826.

[23] Fields, Gary S.. 1990. "Labor market modelling and the urban informal sector: theory and evidence." in The Informal Sector Revisited. OECD ed: OECD. Paris. 
[24] FIEL. 2000. La Economia Oculta en la Argentina. Buenos Aires.

[25] Gasparini, Leonardo C.. 2003. "Proteccion Social y Empleo en America Latina Estudio sobre la Base de Encuestas des Hogares." Panorama Laboral. OIT.

[26] Grindling, T.H. and Katherine Terrell. 2004. "Legal minimum wages and the wages of formal and informal sector workers in Costa Rica." UMBC Department of Economics Working Paper 04-102.

[27] Harris, J.R. and M.P. Todaro. 1970. "Migration, Unemployment and Development: A two sector analysis." American Economic Review 60(1): 126-142.

[28] Harrison, A. and E. Leamer. 1997. "Labor markets in developing countries: an agenda for research." Journal of Labor Economics 15(3): 1-19.

[29] Heckman, James J. and Carmen Pages ed. 2003. Law and Employment: Lessons from the Latin America and the Caribbean : University of Chicago Press.

[30] Inter-American Development Bank. 2004. Good Jobs wanted - Labor Markets in Latin America. Washington DC.

[31] Kostzer, Daniel. 2006. "Argentina: La recuperación del salario mínimo como herramienta de política de ingresos." in ¿Para qué sirve el salario minimo? Elementos para su determinación en los países del Cono sur. Marinakis, Andres and Juan Jacobo Velasco ed: OIT Santiago.

[32] Kristensen, Nicolai and Wendy Cunningham. 2006. "Do minimum wages in Latin America and the Caribbean matter? Evidence from 19 countries." World Bank Policy Research Working Paper No. WPS 3870.

[33] Lemos, Sara. 2004a. "A menu of minimum wage variables of evaluating wages and employment effects: Evidence from Brazil." Working paper, University of Leicester.

[34] Lemos, Sara. 2004b. "The effects of the minimum wage in the formal and informal sectors in Brazil." Working paper No. 04/8, University of Leicester.

[35] Maloney, W. and J. Nunez. 2003. "Measuring the impact of minimum wages: evidence from Latin America." in Law and Employment: Lessons from Latin America 
and the Caribbean. Heckman, James J. and Carmen Pages ed: University of Chicago Press.

[36] Marshall, Adriana. 2004. "Labour market policies and regulations in Argentina, Brazil, and Mexico: Programmes and Impact." Employment Strategy Paper 2004/13. ILO Employment Strategy Department. Geneva.

[37] Mazumdar, Dipak. 1989. "Microeconomic Issues of Labor Markets in Developing Countries: Analysis and Policy Implications." World Bank Economic Development Institute Paper Number 40.

[38] Mcleod, D. and N. Lustig. 1997. " Minimum wages and poverty in developing countries: some empirical evidence." in Labor Markets in Latin America. Sebastian Edwards and Nora Lustig ed: Brookings Institution.

[39] Meyer, Bruce. 1995. "Natural and Quasi-Experiments in Economics." Journal of Business and Economic Statistic 13(2): 151-161.

[40] Ministerio de Trabajo (MTSS). 2004. "Salario Minimo Vital y Movil - Informe." Ministry of Labor, Argentina.

[41] Ministerio de Economia (ME). 2005. Empleo e Ingresos. Ministry of Economy, Argentina.

[42] Montenegro, Claudio and Carmen Pages. 2003. "Who benefits from labor market regulations? Chile 1960-1998." Inter-American Development Bank Working Paper No.494.

[43] Neri, M., G. Gonzaga and J. Camargo. 2000. "Efeitos informais do salario minimo e probeza." Texto Para Discussao No 724, IPEA, Rio de Janeiro.

[44] Rama, Martin. 2001. "What happens when the minimum wage is doubled." Industrial and Labor Relations Review 54(4): 864-886.

[45] Saget, Catherine. 2001. "Is the minimum wage an effective tool to promote decent work and reduce poverty? The experience of selected developing countries." ILO Employment Paper Number 2001/13. ILO Geneva. 
[46] SMERU. 2001. "Wage and employment effects of minimum wage policy in the Indonesian urban labor market." The SMERU Research Institute.

[47] SEL Consultores. 2006. Newsletter sobre la situación laboral y social de la Argentina. www. selconsultores.com.ar

[48] Stewart, Mark B.. 2002. "Estimating the Impact of the Minimum Wage Using Geographical Wage Variation." Oxford Bulletin of Economics and Statistics 64(5): 583-605.

[49] Stewart, Mark B.. 2004. "The Employment Effects of the National Minimum Wage." Economic Journal, 114(494): 110-116.

[50] Szretter, Hector. 2004. "Salario minimo vital y movil: Antecedentes y analysis." Serie Materiales de capacitacion 3, OIT, Argentina.

[51] The World Bank. 2006. Informal Employment in Argentina: Profiling and Dynamics. Report No.36092-AR. Washington D.C. and Argentina. 


\section{Annex 1: Tables and Figures}

Table 1: Minimum Wage Changes, 1980 -2005

Nominal Minimum Wages

\begin{tabular}{|c|c|c|}
\hline 1980 & average & 313037.67 \\
\hline 1981 & average & 625763.42 \\
\hline 1982 & average & 1754985.5 \\
\hline 1983 & average & 1150 \\
\hline 1984 & average & 9155.92 \\
\hline 1985 & average & 47.72 \\
\hline 1986 & average & 88.25 \\
\hline 1987 & October & 350 \\
\hline 1988 & April & 520 \\
\hline 1988 & June & 680 \\
\hline 1988 & August & 924 \\
\hline 1988 & October & 1310 \\
\hline 1989 & January & 1700 \\
\hline 1989 & March & 2100 \\
\hline 1989 & April & 2400 \\
\hline 1989 & May & 4000 \\
\hline 1989 & June & 8700 \\
\hline 1989 & July & 20000 \\
\hline 1989 & average & 11717 \\
\hline 1990 & & 20000 \\
\hline 1990 & September & 720000 \\
\hline 1990 & average & 253333 \\
\hline 1991 & & 720000 \\
\hline 1991 & March & 970000 \\
\hline 1991 & average & 868333 \\
\hline 1992 & July & 97 \\
\hline 1993 & August & 200 \\
\hline 1994 & & 200 \\
\hline 1995 & & 200 \\
\hline 1996 & & 200 \\
\hline 1997 & & 200 \\
\hline 1998 & & 200 \\
\hline 1999 & & 200 \\
\hline 2000 & & 200 \\
\hline 2001 & & 200 \\
\hline 2002 & & 200 \\
\hline 2003 & July & 250 \\
\hline & August & 260 \\
\hline & September & 270 \\
\hline & October & 280 \\
\hline & November & 290 \\
\hline & December & 300 \\
\hline 2004 & January & 350 \\
\hline & September & 450 \\
\hline 2005 & May & 510 \\
\hline & June & 570 \\
\hline & July & 630 \\
\hline \multicolumn{3}{|c|}{ Note: 1) Monthly urban minimum wages } \\
\hline \multicolumn{3}{|c|}{$\begin{array}{l}\text { 2) Effective after 1.3.1992 } 1 \text { Peso }=10,000 \text { Australes, } \\
\text { Argentine Peso thereafter. }\end{array}$} \\
\hline \multicolumn{3}{|c|}{ 3) Minimum wage increases of interest in bold. } \\
\hline $\begin{array}{l}\text { Sources: ILO } \\
\text { MTSS Informe }\end{array}$ & $\begin{array}{l}\text { LABMINW, Mi } \\
\text { e Enero } 2004 \text {, }\end{array}$ & $\begin{array}{l}\text { stery of Economy, } \\
\text { nuario-93 }\end{array}$ \\
\hline
\end{tabular}


Table 2: Area-level Difference-in-Difference estimate: Wage Impact

\begin{tabular}{|c|c|c|c|}
\hline \multicolumn{4}{|c|}{ Difference-in-Difference estimates of minimum wage impact on wage } \\
\hline \multirow[t]{2}{*}{ Dependent variable: wage } & \multicolumn{3}{|c|}{$\begin{array}{l}\text { Difference-in-Difference } \\
\text { mean-area-level estimate }\end{array}$} \\
\hline & $\theta$ & t-test & $p$-value \\
\hline No controls: & & & \\
\hline Informal sector wage & 1.45 & [ 0.13 ] & 0.90 \\
\hline Formal sector wage & 6.89 & {$[0.10$ ] } & 0.92 \\
\hline wage (formal and informal) & -0.92 & {$[-0.03]$} & 0.98 \\
\hline With local area control: & & & \\
\hline Informal sector wage & 1.45 & {$[0.15]$} & 0.88 \\
\hline Formal sector wage & 6.89 & {$[0.11]$} & 0.91 \\
\hline wage (formal and informal) & -0.92 & {$[-0.04]$} & 0.97 \\
\hline
\end{tabular}

Note: ${ }^{*}$ significant at $10 \% ;{ }^{* \star}$ significant at $5 \%$; ${ }^{* \star *}$ significant at $1 \%$

$1 /$ Labour income

2/ Robust t-ratios in parentheses.

3/ Local area control: GDP by province

Source: own calculations based on EPH, INDEC.

Table 3: Individual-level Difference-in-Difference estimate: Wage Impact -No controls

\begin{tabular}{|c|c|c|c|c|}
\hline \multicolumn{5}{|c|}{ Difference-in-Difference estimates of minimum wage impact on wage } \\
\hline \multirow{2}{*}{$\begin{array}{l}\text { Dependent variable: wage } \\
\text { No controls }\end{array}$} & \multicolumn{4}{|c|}{$\begin{array}{l}\text { Difference-in-Difference } \\
\text { individual level estimate, } \theta\end{array}$} \\
\hline & $\theta$ & t-test & p-value & \\
\hline Informal sector wage & 5.01 & [1.90] & 0.074 & ** \\
\hline Formal sector wage & 21.22 & {$[1.19]$} & 0.251 & \\
\hline wage (formal and informal) & 6.56 & {$[1.78]$} & 0.093 & ** \\
\hline
\end{tabular}

Note: * significant at $10 \% ;{ }^{* *}$ significant at $5 \% ;{ }^{* * *}$ significant at $1 \%$

1/ Labour income.

2/ Robust t-ratios in parentheses.

3/ The t-ratios for the individual level equations are based on standard errors

that allow for "clustering" by area.

Source: own estimations based on EPH, INDEC. 
Table 4: Individual-level Difference-in-Difference estimate: Wage Impact -With Controls

\begin{tabular}{|c|c|c|c|c|c|}
\hline \multicolumn{6}{|c|}{ Difference-in-Difference estimates of minimum wage impact on wage } \\
\hline Dependent variable: wage & & \multicolumn{4}{|c|}{$\begin{array}{l}\text { Difference-in-Difference } \\
\text { individual level estimate, } \theta\end{array}$} \\
\hline With controls & & $\theta$ & t-test & p-value & \\
\hline (1) industry sector controls & & & & & \\
\hline Informal sector wage & & 38.51 & [4.85] & 0.00 & *** \\
\hline Formal sector wage & & 20.88 & [1.13] & 0.273 & \\
\hline wage (formal and informal) & & 39.43 & [3.01] & 0.008 & *** \\
\hline (2) industry sector and individual controls & $3 /$ & & & & \\
\hline Informal sector wage & & 33.91 & [4.38] & 0.00 & *** \\
\hline Formal sector wage & & 14.31 & [0.83] & 0.418 & \\
\hline wage (formal and informal) & & 31.76 & [3.52] & 0.003 & $* * *$ \\
\hline (3) local area controls & $4 /$ & & & & \\
\hline Informal sector wage & & 36.86 & {$[4.54]$} & 0.00 & *** \\
\hline Formal sector wage & & 20.15 & [1.10] & 0.289 & \\
\hline wage (formal and informal) & & 38.55 & [2.99] & 0.008 & *** \\
\hline
\end{tabular}

Note: * significant at $10 \% ;{ }^{* *}$ significant at $5 \% ;{ }^{* * *}$ significant at $1 \%$

$1 /$ Robust t-ratios in parentheses.

2/ The t-ratios for the individual level equations are based on standard errors

that allow for "clustering" by area.

3/ Individual level controls: gender, age and education.

4/ Local area controls: GDP by province and industry sector.

Source: own estimations based on EPH, INDEC. 
Figure 1: Nominal and real national minimum wage, 1992-2005

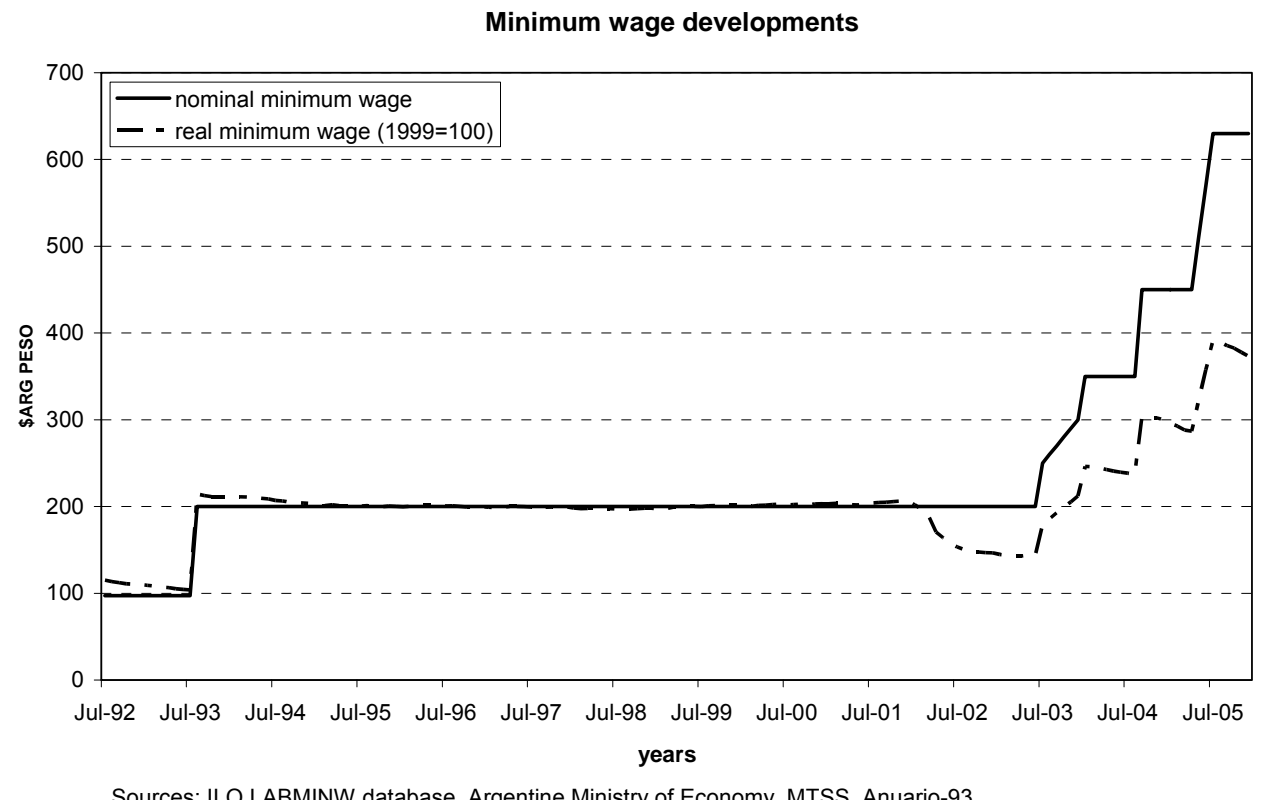

Figure 2: Minimum wage and basic consumption, 2000-2005

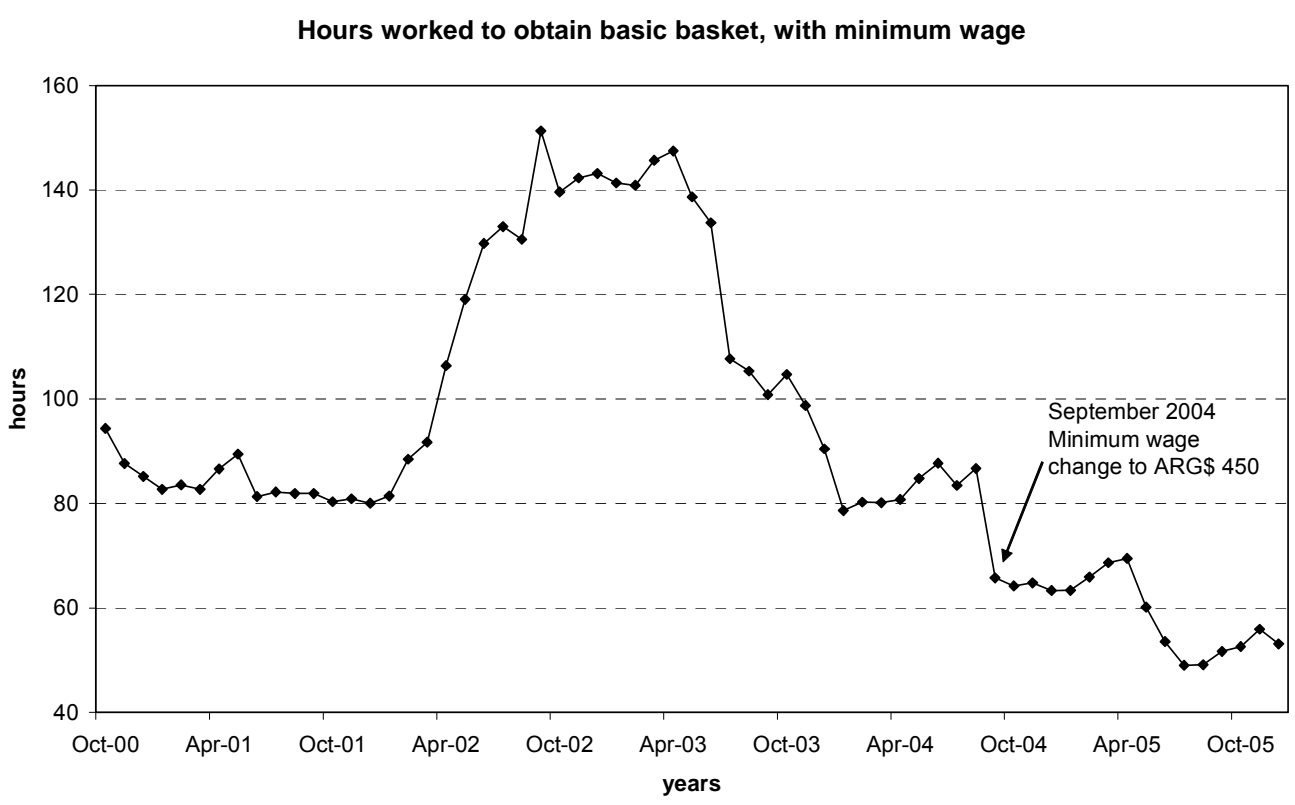

Source: own calculations based on Argentine Ministry of Economy (2005). Consumer Prices from INDEC. 
Figure 3: Informality in the labor market developments, 1990-2005

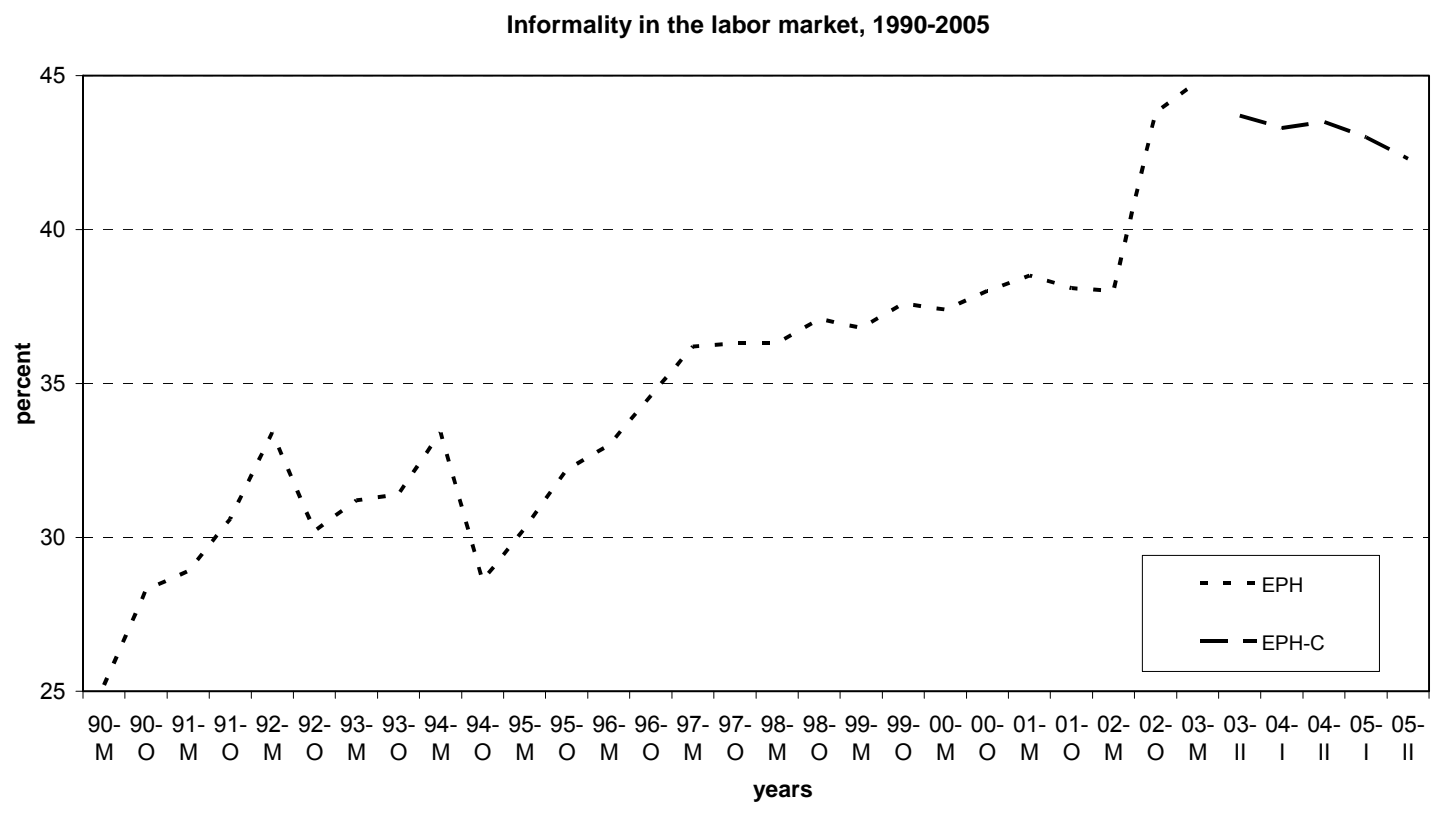

Note: M: May. O: October. I: 1st semester. II: 2nd semester.

Source: Data from Ministery of Economy (2006) and from CEDLAS (2006).

Figure 4: Kernel density (total) - labor income (formal and informal)

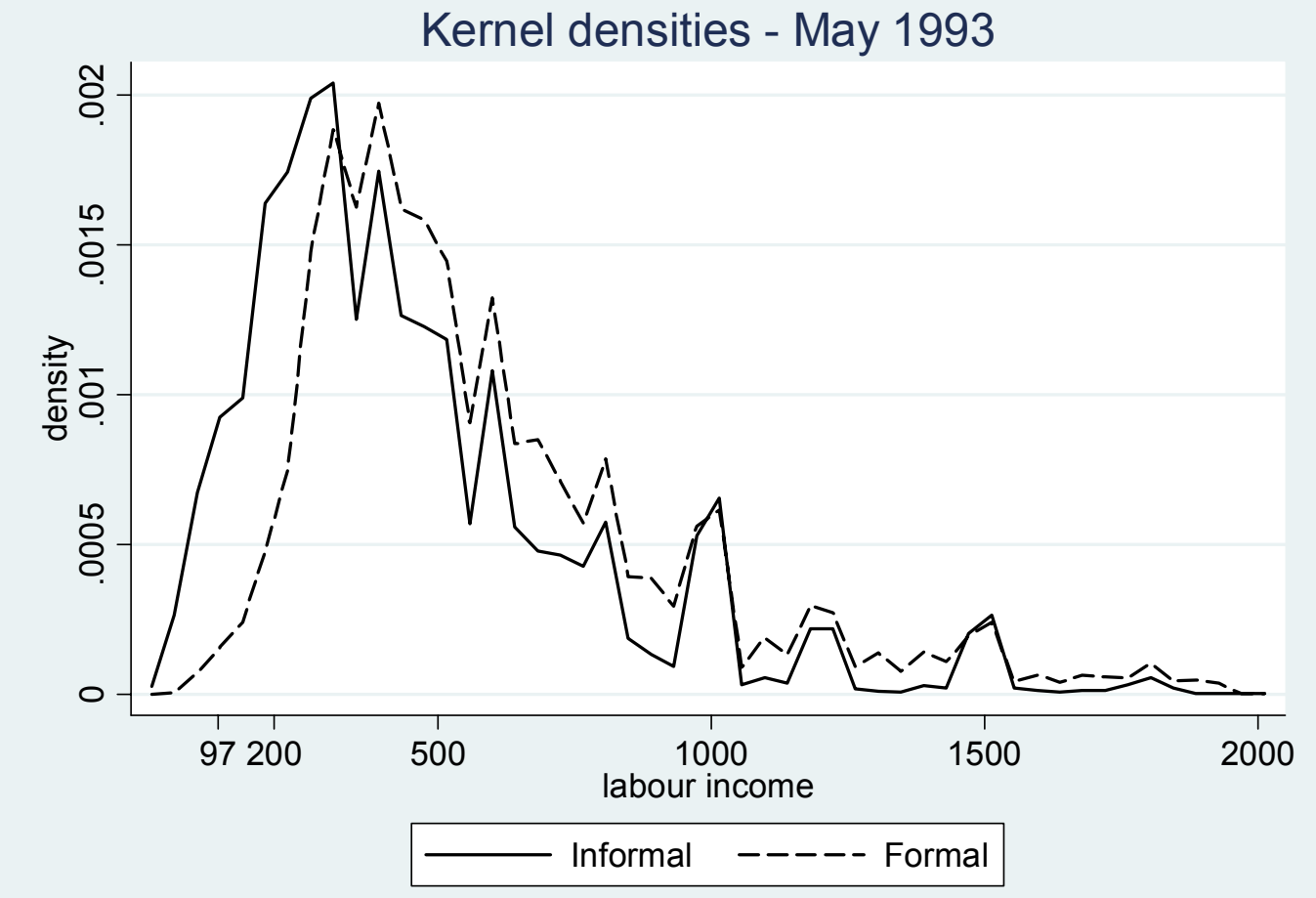

Source: own estimations based on EPH. 
Figure 5: Kernel density (lower end) - labor income (formal and informal

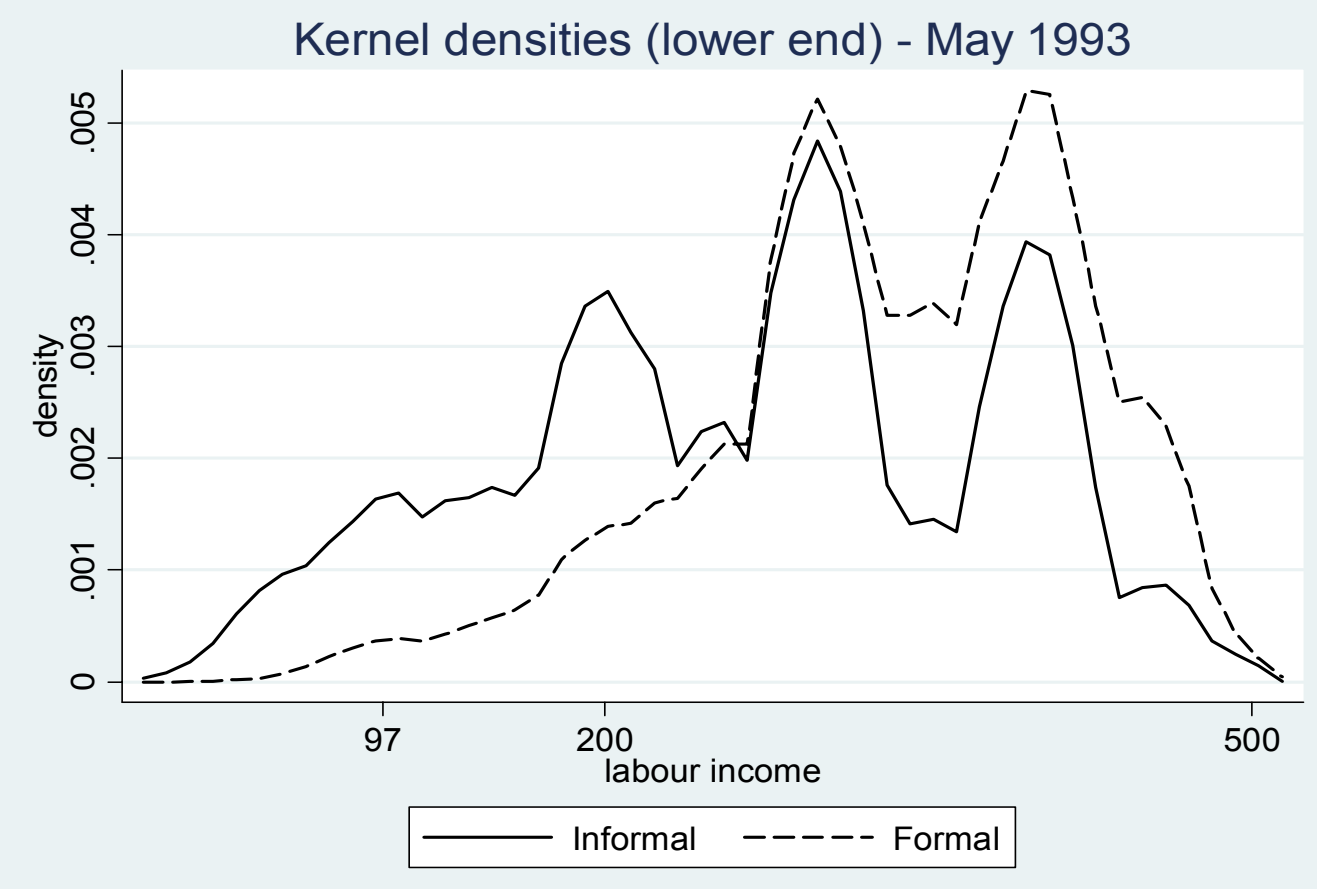

Source: own estimations based on EPH.

Figure 6: Cumulative distribution - labor income (formal and informal)

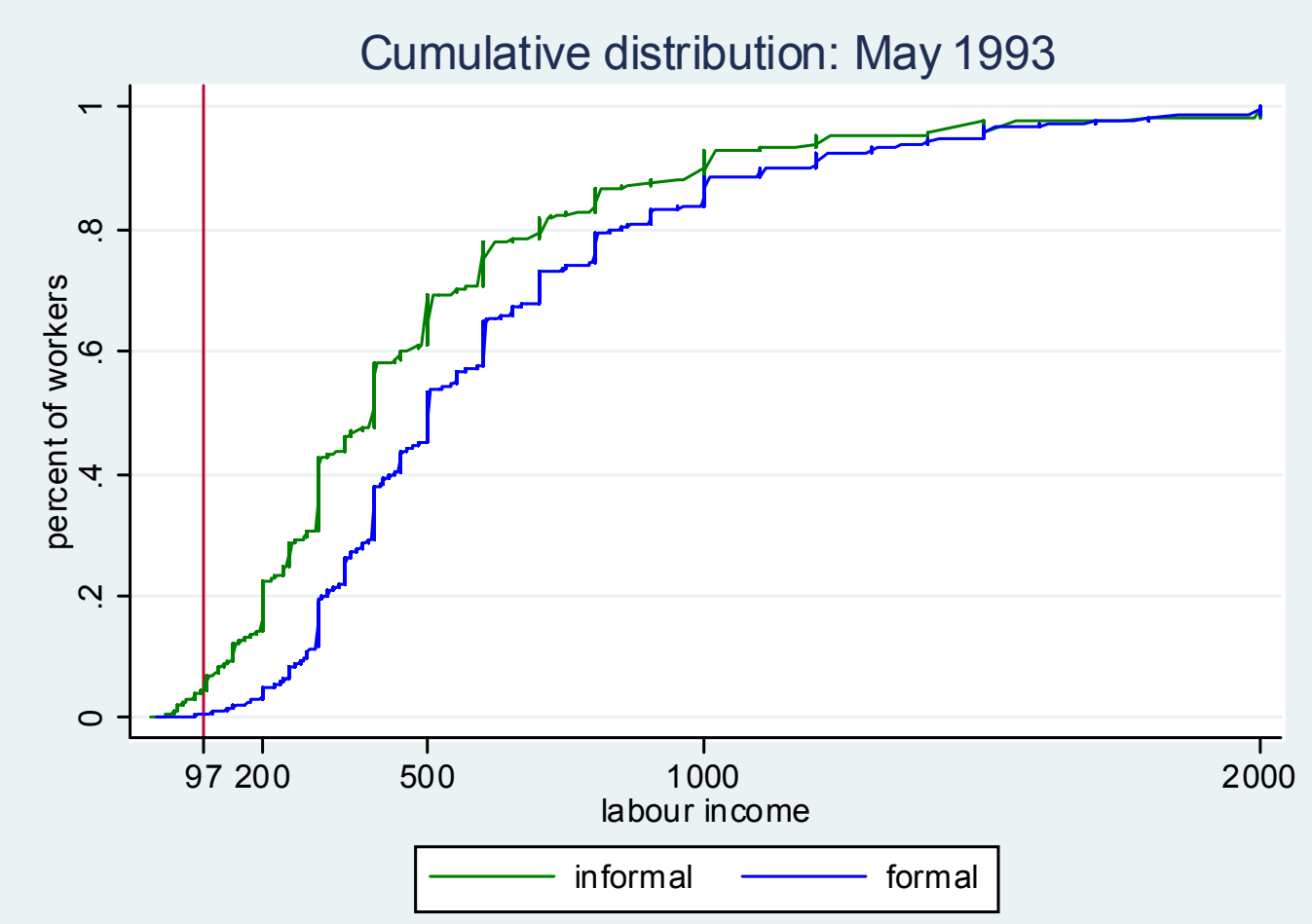

Source: own estimations based on EPH. 
Figure 7: Kernel density (total) - labor income by urban area
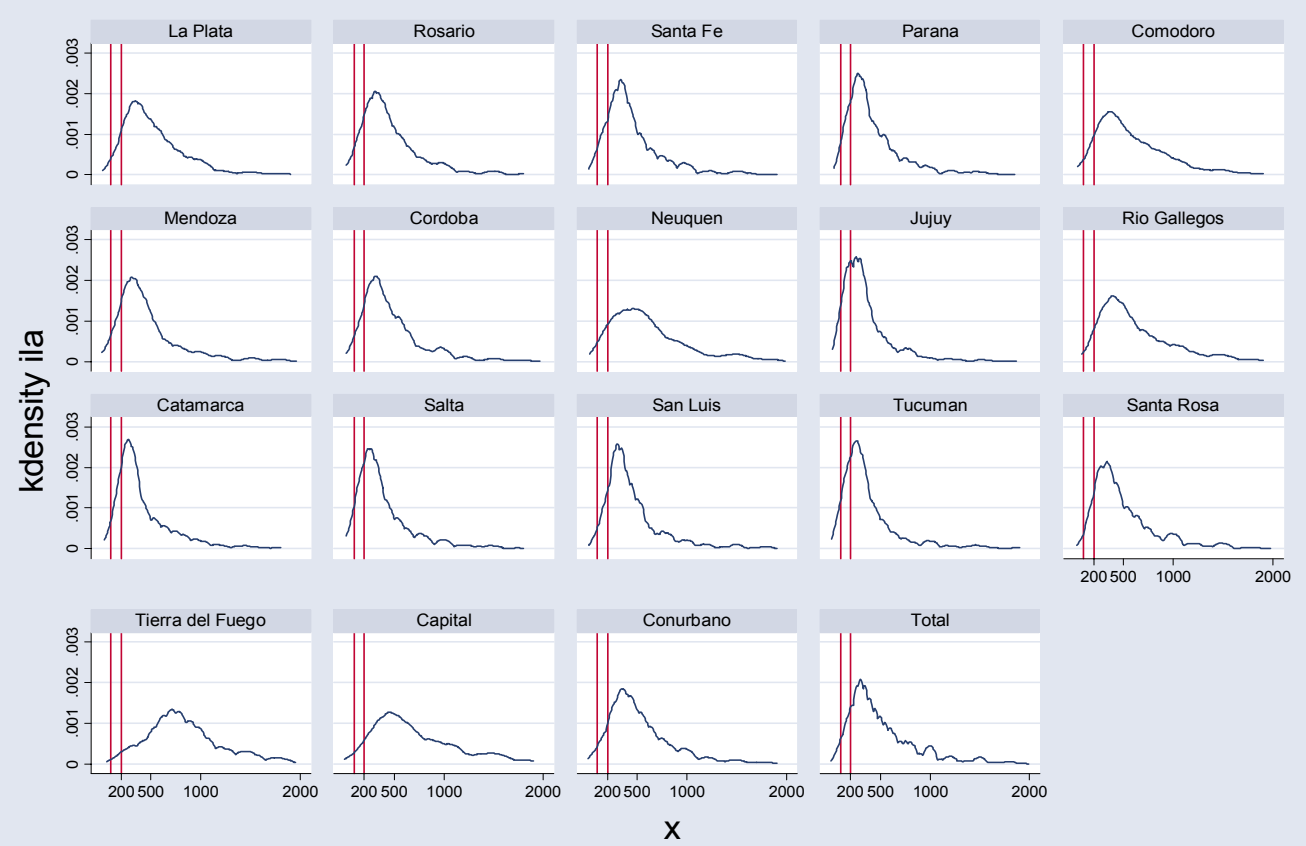

Graphs by town

Source: own estimations based on EPH.

Figure 8: Scatter plot of percentage below minimum wage, by urban area

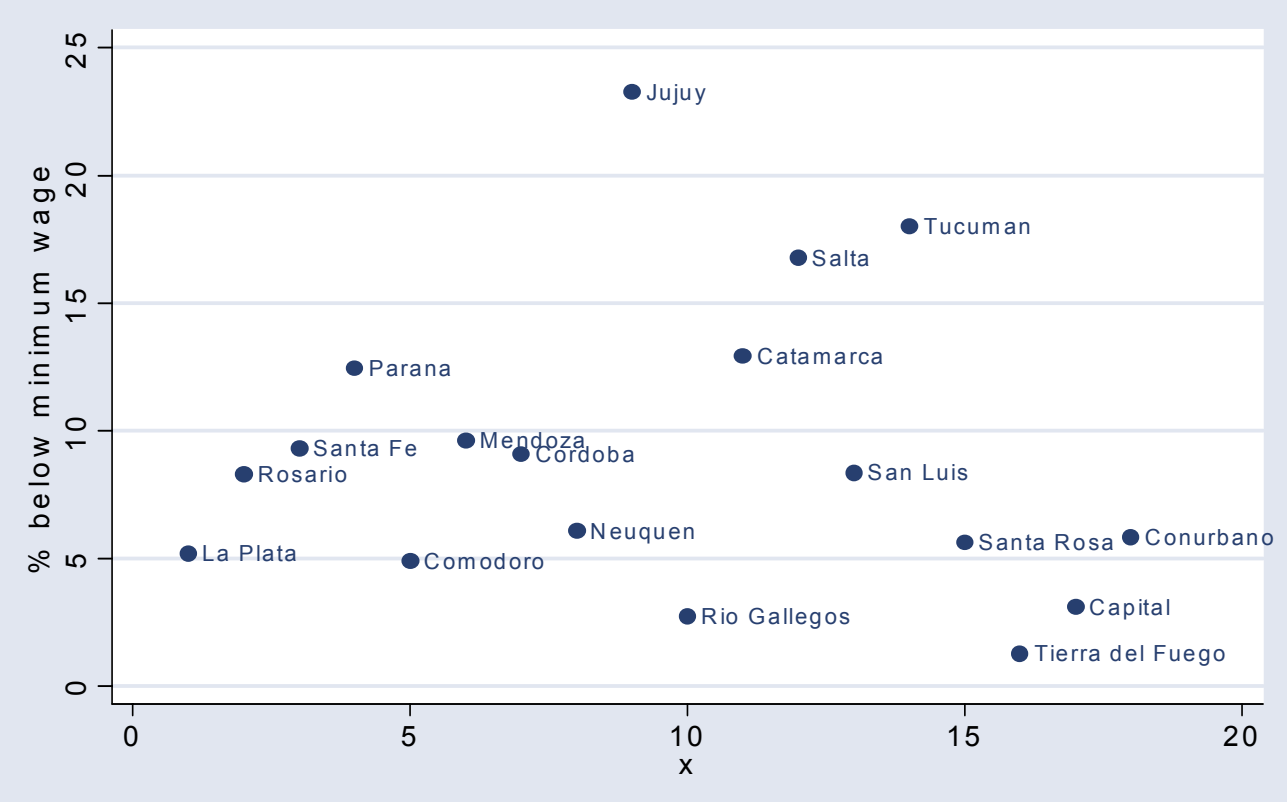

Source: own estimations based on EPH. 
Figure 9: Kernel density - High and Low impact areas

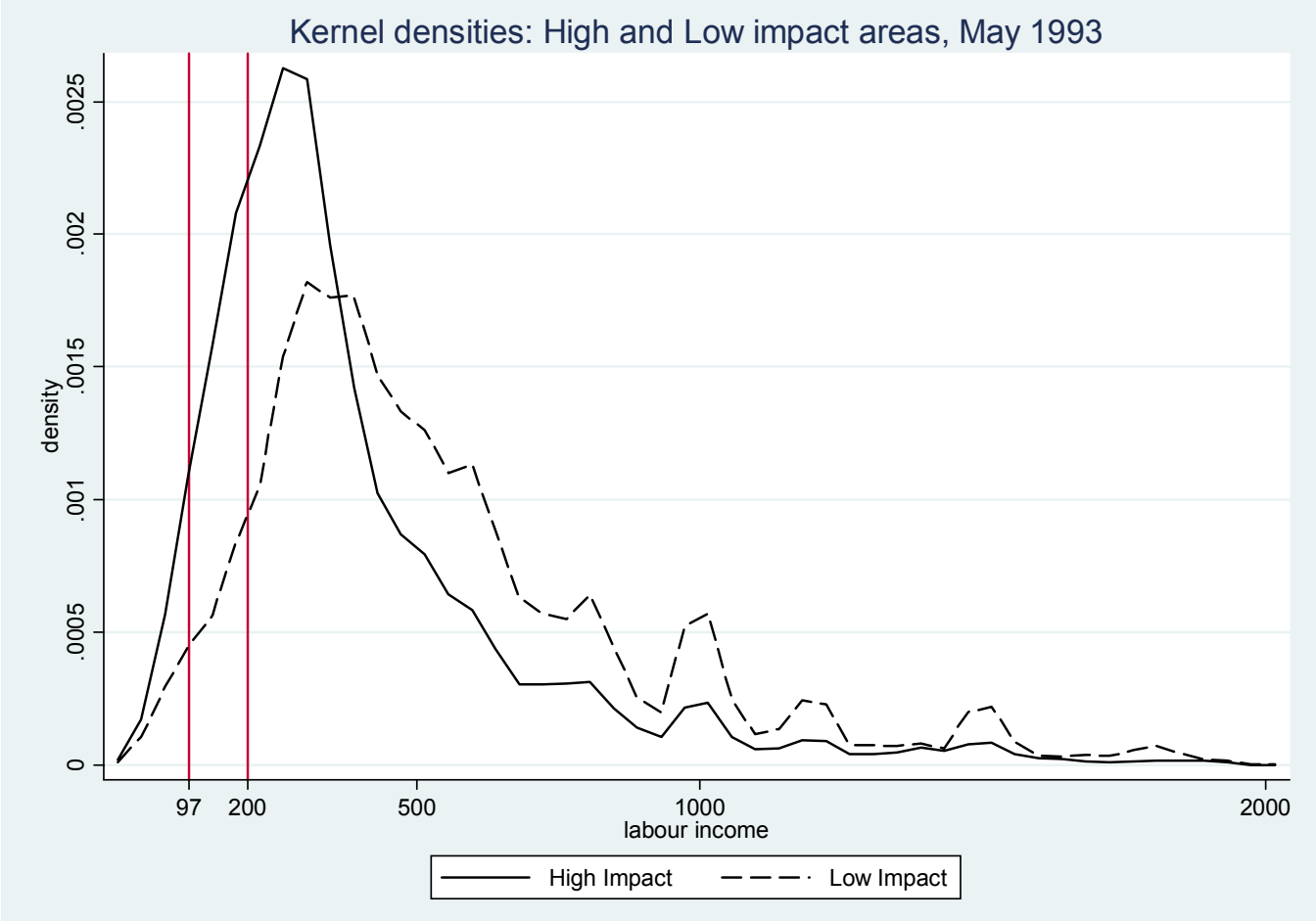

Source: own estimations based on EPH.

Figure 10: Change in area wage distributions, total

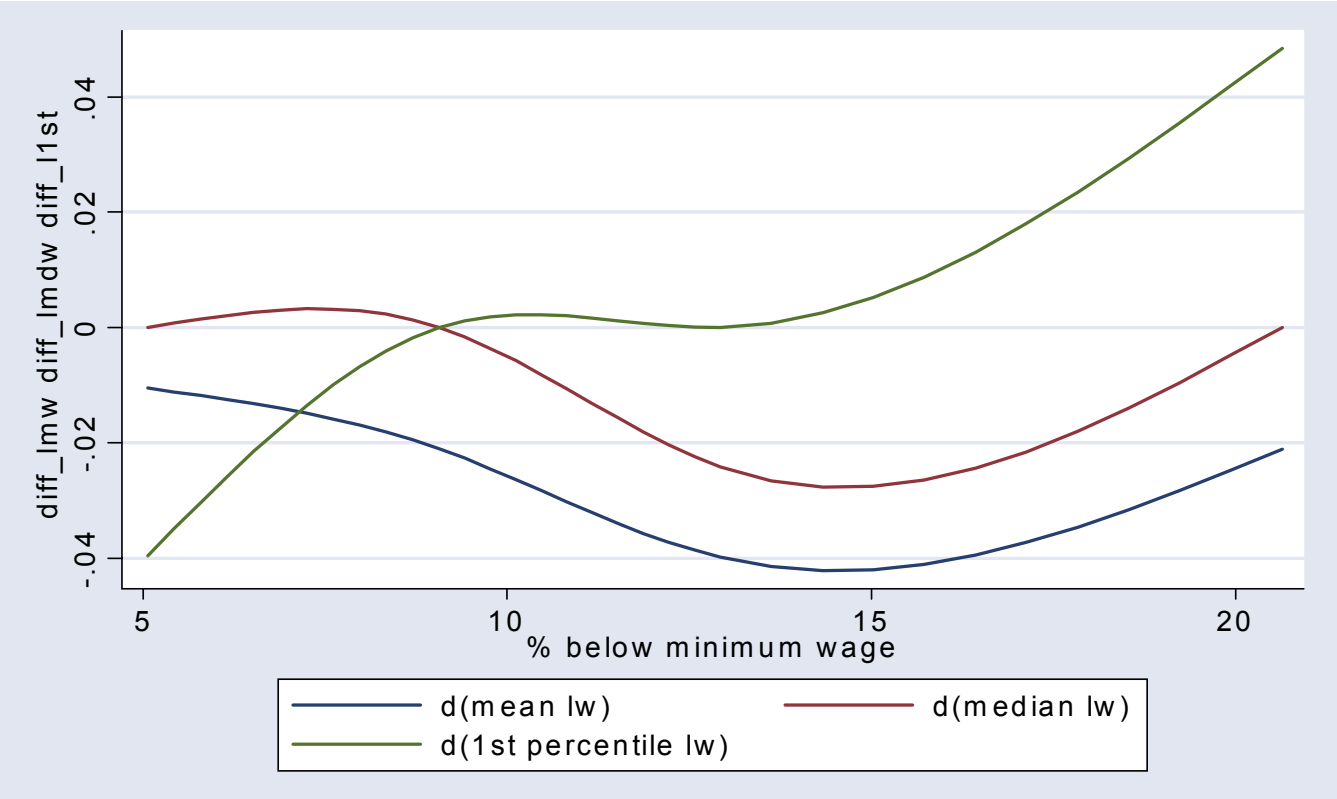

Source: own estimations based on EPH. 
Figure 11: Kernel density - wage (formal and informal)

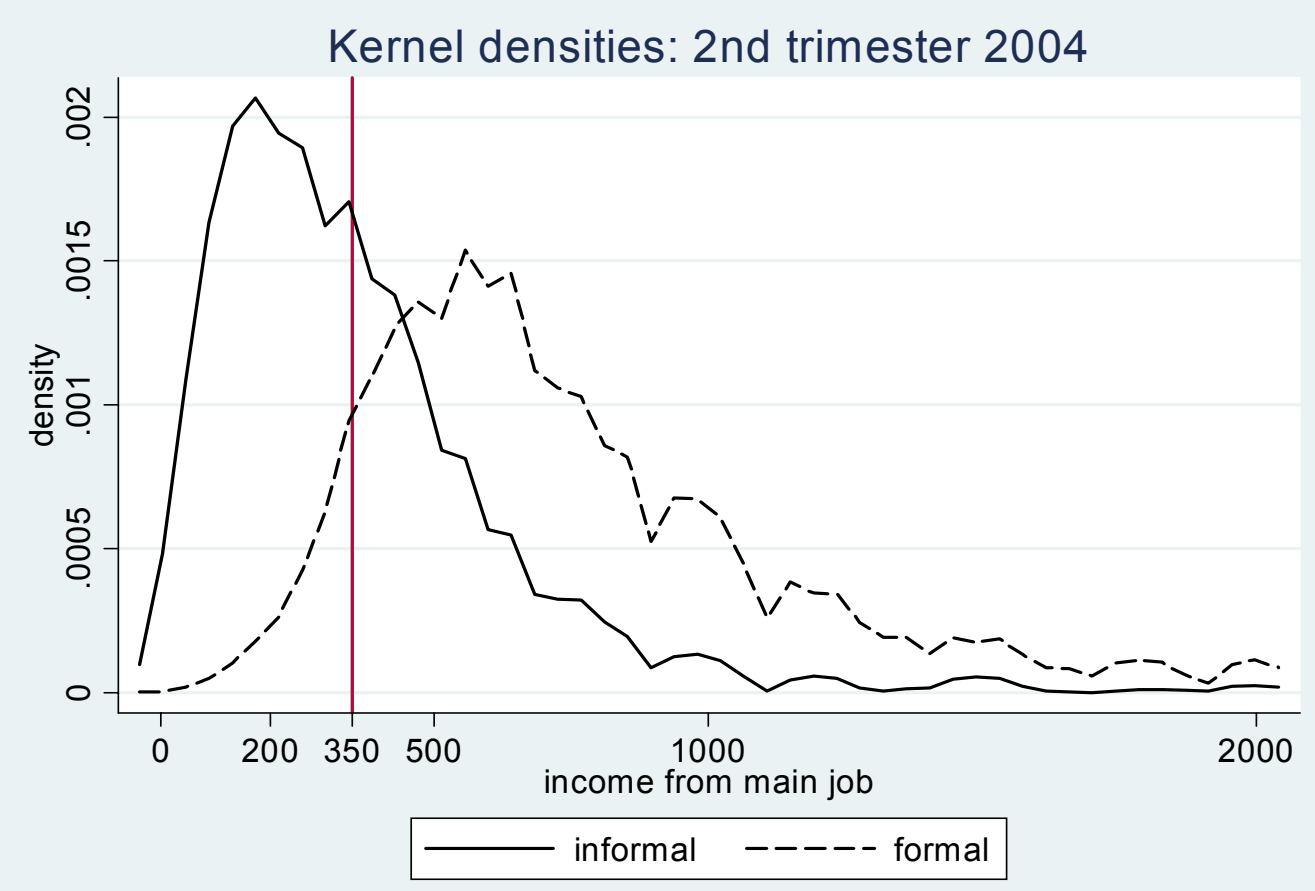

Source: own calculations based on EPH-C.

Figure 12: Cumulative distribution - wage (formal and informal)

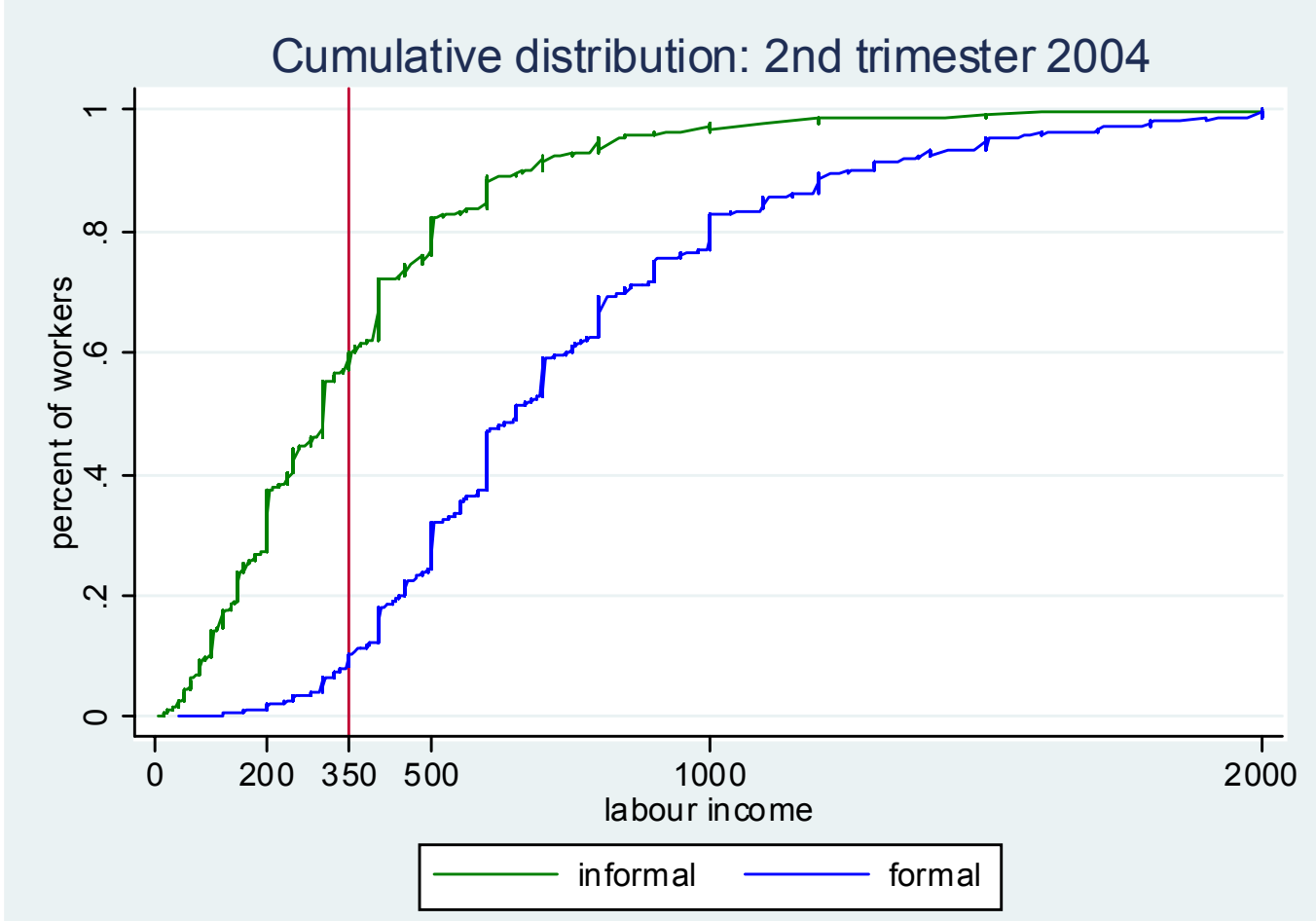

Source: own calculations based on EPH-C. 
Figure 13: Kernel density - wage (formal and informal)

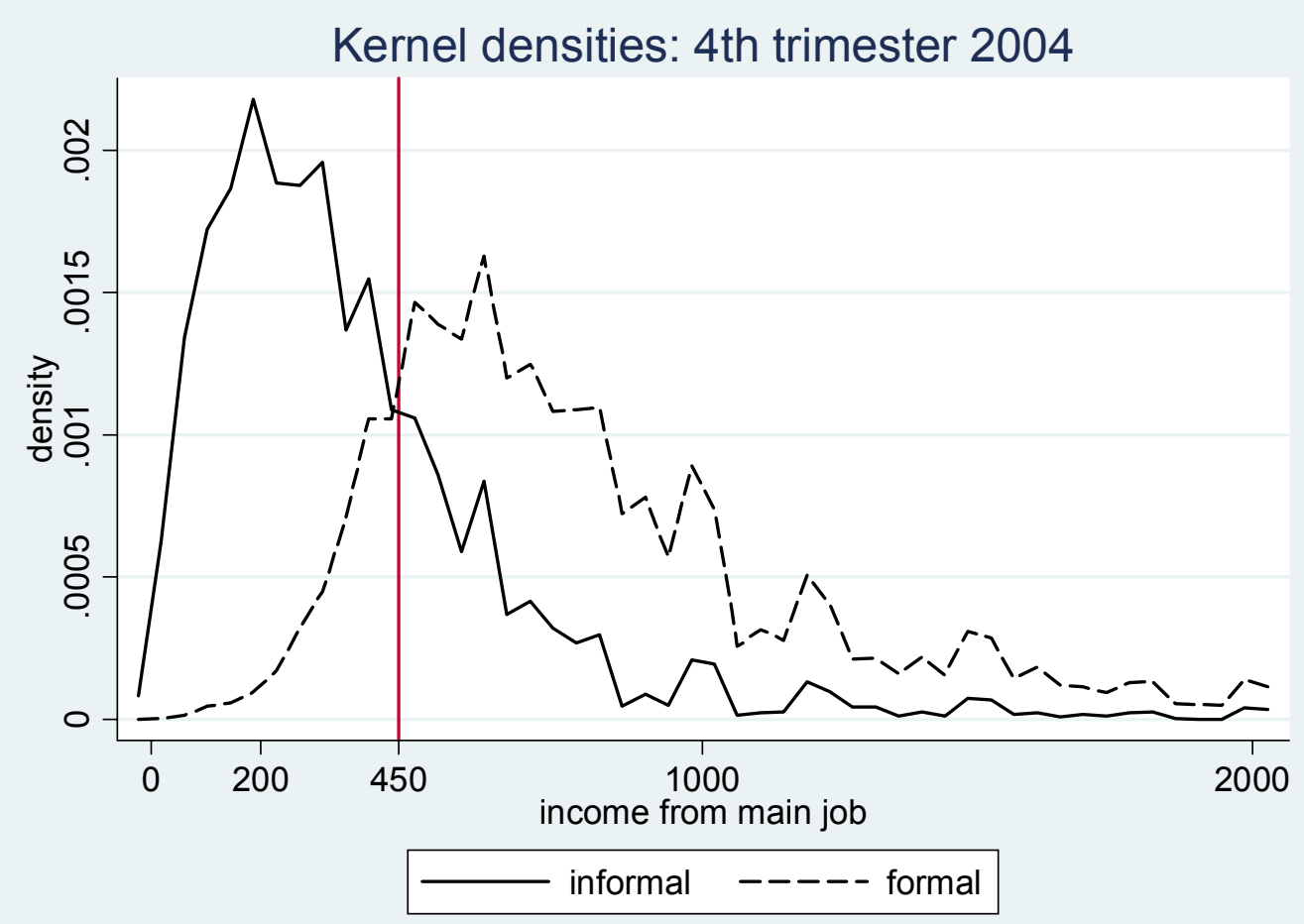

Source: own calculations based on EPH-C.

Figure 14: Cumulative distribution - wage (formal and informal)

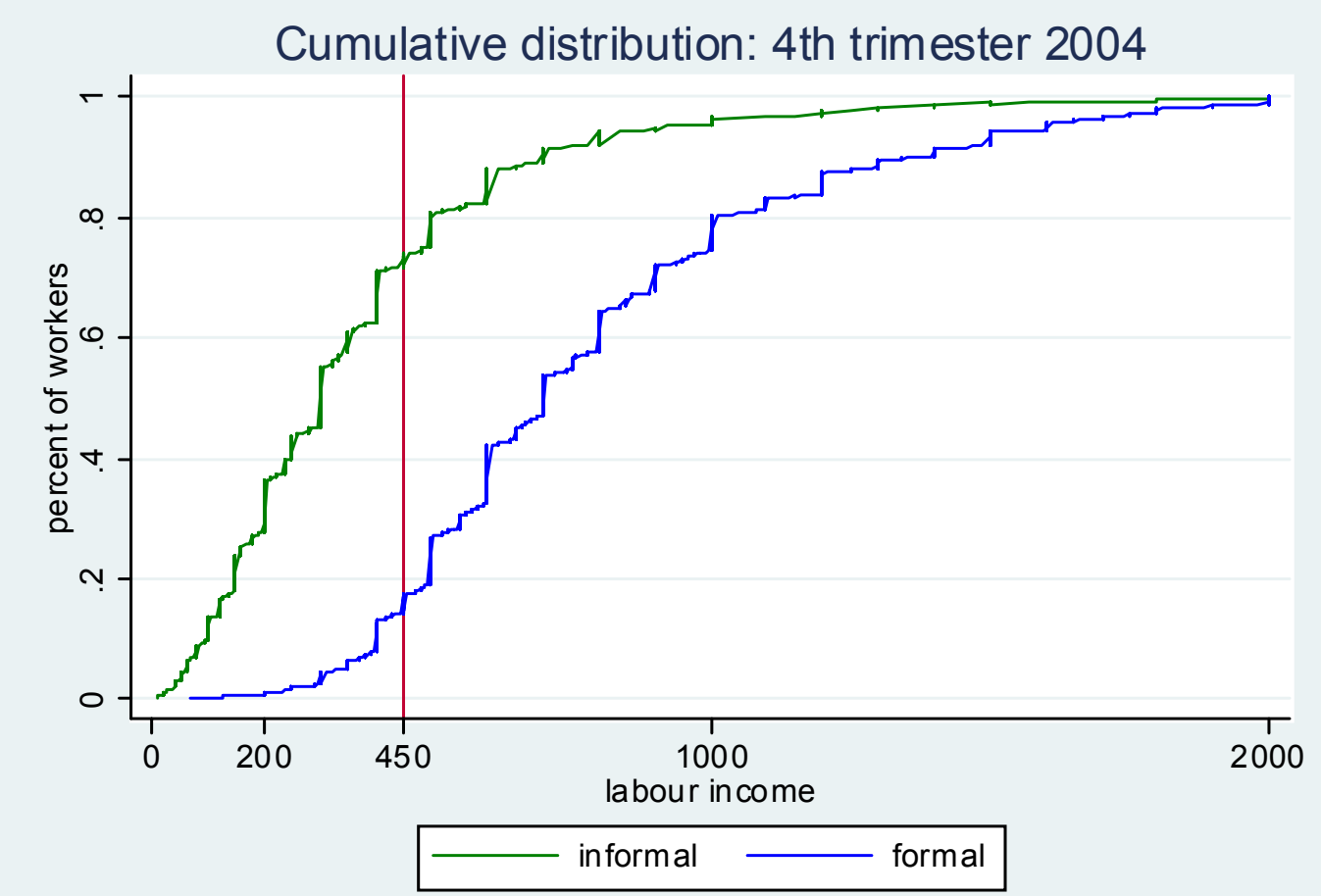

Source: own calculations based on EPH-C. 


\section{Annex 2: Descriptive Statistics and Variable Description}

Table 5: Characteristics of wage earners at or below the minimum wage, 1993

\begin{tabular}{|c|c|c|}
\hline \multicolumn{3}{|c|}{ Characteristics of wage earners at or below minimum wage, weighted, May and October 1993} \\
\hline & May 1993 & October 1993 \\
\hline \multicolumn{3}{|l|}{ Role in Household } \\
\hline Head & 24.58 & 31.12 \\
\hline Spouse & 31.74 & 26.79 \\
\hline Child & 35.02 & 32.33 \\
\hline \multicolumn{3}{|l|}{ Age } \\
\hline below 15 & 12.58 & 5.29 \\
\hline 16 to 25 & 27.18 & 28.58 \\
\hline 26 to 40 & 22.73 & 25.61 \\
\hline 41 to 64 & 28.59 & 32.86 \\
\hline above 65 & 8.92 & 7.66 \\
\hline \multicolumn{3}{|l|}{ Sex } \\
\hline Male & 27.90 & 43.00 \\
\hline Female & 72.10 & 57.00 \\
\hline \multicolumn{3}{|l|}{ Education } \\
\hline primary incomplete & 22.14 & 20.27 \\
\hline primary complete & 30.80 & 36.21 \\
\hline secondary incomplete & 21.53 & 20.94 \\
\hline secondary complete & 5.20 & 10.79 \\
\hline teritary incomplete & 8.68 & 5.64 \\
\hline teritary complete & 6.74 & 4.19 \\
\hline \multicolumn{3}{|l|}{ Labour market sectors } \\
\hline Formal & 10.67 & 17.95 \\
\hline Informal & 89.33 & 82.05 \\
\hline \multicolumn{3}{|l|}{ Occupation } \\
\hline primary & 96.59 & 96.13 \\
\hline secondary & 3.41 & 3.87 \\
\hline \multicolumn{3}{|l|}{ Wealth Deciles } \\
\hline 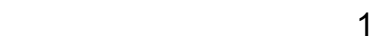 & 16.12 & 17.20 \\
\hline 2 & 11.70 & 8.62 \\
\hline 3 & 15.61 & 9.61 \\
\hline 4 & 13.28 & 12.03 \\
\hline 5 & 5.84 & 9.87 \\
\hline 6 & 9.34 & 11.08 \\
\hline 7 & 9.10 & 10.93 \\
\hline 8 & 6.91 & 8.07 \\
\hline 9 & 8.92 & 7.82 \\
\hline 10 & 3.18 & 4.76 \\
\hline Sample Size & 490 & 3264 \\
\hline Population & 125,972 & 645,909 \\
\hline \multicolumn{3}{|l|}{ Note: } \\
\hline \multirow{2}{*}{\multicolumn{3}{|c|}{$\begin{array}{l}\text { 1/ All numbers are in percent for employees and self-employed and frequency unless stated otherwise. } \\
\text { 2/ Minimum wage is } 97 \text { Peso for May and } 200 \text { Peso for October. }\end{array}$}} \\
\hline & & \\
\hline \multicolumn{3}{|c|}{ 3/ Wealth deciles, total family income. } \\
\hline Source: own calculations based $\mathrm{c}$ & C. & \\
\hline
\end{tabular}


Table 6: High impact and low impact group characteristics Comparison of the "high impact" and "low impact" groups (May 1993) 1/

\begin{tabular}{|c|c|c|}
\hline Sample size (based on total below minimum wage) & $\begin{array}{c}\text { "High impact" group 2/ } \\
1093\end{array}$ & $\begin{array}{c}\text { "Low impact" group 3/ } \\
1219\end{array}$ \\
\hline Mean monthly wage $4 /$ & 415.46 & 643.49 \\
\hline Median monthly wage & 300 & 500 \\
\hline 1st percentile wage & 50 & 60 \\
\hline 5th percentile wage & 100 & 150 \\
\hline 10th percentile wage & 145 & 200 \\
\hline Proportion of "low paid"/ bite 5/ & 16.68 & 6.11 \\
\hline
\end{tabular}

Note:

1/ Divided by proportion of initially earning below the new minimum wage.

2/ High impact group includes: Parana, Jujuy, Catamarca, Salta and Tucuman.

$3 /$ Low impact group includes the rest of the urban areas.

4/ In ARG\$ Peso.

5/ Averages.

Source: own calculations based on the EPH, INDEC.

Table 7: Variable description

\section{Variable Descriptions for DID estimations}

$\begin{array}{ll}\text { wage } & \text { monthly labour income of waged work and self-employed } \\ \text { local area controls } & \text { GDP per capita by province } \\ \text { industry sector } & \text { industry dummy } \\ \text { individual controls } & \text { gender dummy, education level dummy, age }\end{array}$


Table 8: Characteristics of wage earners at or below the minimum wage, 2004

\begin{tabular}{|c|c|c|}
\hline \multicolumn{3}{|c|}{ Characteristics of wage earners at or below minimum wage, weighted, 2nd and 4th trimester 2004} \\
\hline & 2nd trimester 2004 & 4th trimester 2004 \\
\hline \multicolumn{3}{|l|}{ Role in the Household } \\
\hline Head & 39.35 & 39.32 \\
\hline Spouse & 24.46 & 23.63 \\
\hline Child & 28.98 & 29.00 \\
\hline \multicolumn{3}{|l|}{ Marital Status } \\
\hline Married & 51.13 & 52.31 \\
\hline Single & 36.24 & 36.29 \\
\hline \multicolumn{3}{|l|}{ Age } \\
\hline below 14 & 0.78 & 0.49 \\
\hline 15 to 25 & 26.02 & 27.04 \\
\hline 26 to 35 & 22.76 & 24.76 \\
\hline 36 to 45 & 18.05 & 17.74 \\
\hline 46 to 55 & 16.77 & 15.41 \\
\hline 56 to 65 & 10.64 & 10.57 \\
\hline above 66 & 4.99 & 4.00 \\
\hline \multicolumn{3}{|l|}{ Sex } \\
\hline Male & 46.96 & 49.55 \\
\hline Female & 53.04 & 50.45 \\
\hline \multicolumn{3}{|l|}{ Education } \\
\hline primary incomplete & 13.33 & 11.05 \\
\hline primary complete & 30.66 & 31.13 \\
\hline secondary incomplete & 20.90 & 20.93 \\
\hline secondary complete & 17.46 & 18.44 \\
\hline teritary incomplete & 11.48 & 11.64 \\
\hline teritary complete & 6.17 & 6.82 \\
\hline \multicolumn{3}{|l|}{ Labour market sectors } \\
\hline Formal & 18.46 & 22.09 \\
\hline Informal & 81.54 & 77.91 \\
\hline \multicolumn{3}{|l|}{ Industry Sectors } \\
\hline Primary & 1.27 & 0.95 \\
\hline Manufacturing & 12.39 & 13.70 \\
\hline Construction & 10.23 & 10.12 \\
\hline Trade & 27.82 & 27.27 \\
\hline Public Services & 3.89 & 5.61 \\
\hline Financial Services & 4.90 & 5.42 \\
\hline Public Administration & 3.04 & 3.39 \\
\hline Education, health, other services & 36.47 & 33.56 \\
\hline \multicolumn{3}{|l|}{ Firm size } \\
\hline 1 to 5 employees & 77.63 & 71.88 \\
\hline 6 to 40 employees & 14.61 & 18.34 \\
\hline more than 40 employees & 7.76 & 9.78 \\
\hline Sample Size & 5209 & 6506 \\
\hline Population & $2,300,692$ & $3,043,110$ \\
\hline
\end{tabular}

